\title{
The role of host elF2a in viral infection
}

\author{
Yuanzhi Liu ${ }^{1,2,3 \dagger}$, Mingshu Wang ${ }^{1,2,3 \dagger}$, Anchun Cheng ${ }^{1,2,3^{*}}$ (D), Qiao Yang ${ }^{1,2,3}$, Ying Wu ${ }^{1,2,3}$, Renyong Jia ${ }^{1,2,3}$,

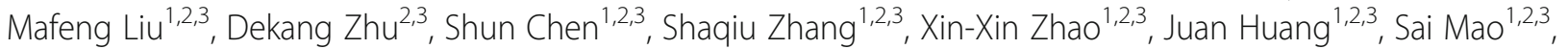

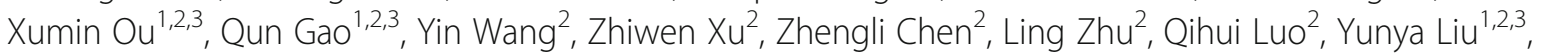 \\ Yanling Yu ${ }^{1,2,3}$, Ling Zhang ${ }^{1,2,3}$, Bin Tian ${ }^{1,3}$, Leichang Pan ${ }^{1,3}$, Mujeeb Ur Rehman ${ }^{1,3}$ and Xiaoyue Chen ${ }^{1,2,3}$
}

\begin{abstract}
Background: elF2a is a regulatory node that controls protein synthesis initiation by its phosphorylation or dephosphorylation. General control nonderepressible-2 (GCN2), protein kinase R-like endoplasmic reticulum kinase (PERK), double-stranded RNA (dsRNA)-dependent protein kinase (PKR) and heme-regulated inhibitor (HRI) are four kinases that regulate elF2a phosphorylation.

Main body: In the viral infection process, dsRNA or viral proteins produced by viral proliferation activate different

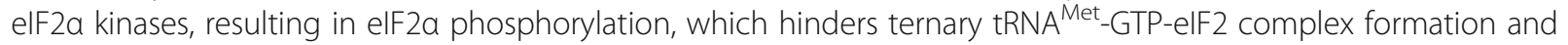
inhibits host or viral protein synthesis. The stalled messenger ribonucleoprotein (mRNP) complex aggregates under viral infection stress to form stress granules (SGs), which encapsulate viral RNA and transcription- and translationrelated proteins, thereby limiting virus proliferation. However, many viruses have evolved a corresponding escape mechanism to synthesize their own proteins in the event of host protein synthesis shutdown and SG formation caused by elF2a phosphorylation, and viruses can block the cell replication cycle through the PERK-elF2a pathway, providing a favorable environment for their own replication. Subsequently, viruses can induce host cell autophagy or apoptosis through the elF2a-ATF4-CHOP pathway.
\end{abstract}

Conclusions: This review summarizes the role of elF2a in viral infection to provide a reference for studying the interactions between viruses and hosts.

Keywords: Virus, elF2a, General translation inhibition, Stress granule, Cell replication cycle, Autophagy/apoptosis

\section{Background}

Cellular DNA undergoes transcription, mRNA translation and processing/modification to form protein molecules with certain structures and functions. During this process, translation initiation is an important step in protein synthesis, which requires the participation of many eukaryotic initiation factors.

\footnotetext{
* Correspondence: chenganchun@vip.163.com

${ }^{\dagger}$ Yuanzhi Liu and Mingshu Wang contributed equally to this work as first authors.

${ }^{1}$ Institute of Preventive Veterinary Medicine, Sichuan Agricultural University, Wenjiang, Chengdu City, Sichuan 611130, P.R. China

${ }^{2}$ Key Laboratory of Animal Disease and Human Health of Sichuan Province, Sichuan Agricultural University, Wenjiang, Chengdu City, Sichuan 611130, P.R. China

Full list of author information is available at the end of the article
}

eIF2, which is required for the initiation of most eukaryotic translation (Fig. 1), mediates the binding of Met-tRNAi ${ }^{\text {Met }}$ and the ribosomal 40S subunit in a GTPdependent manner and initiates peptide chain synthesis. Under normal circumstances, the GTP conversion factor eIF2B converts inactive eIF2-GDP into active eIF2-GTP. Next, eIF2-GTP, Met-tRNAi ${ }^{\text {Met }}$, the ribosomal 40S subunit and other components (i.e., eIF1, eIF1A and eIF3) form the 43S complex, which scans for the initiation codon, AUG, along the mRNA. After the initiation codon is recognized, GTP bound to eIF2 is hydrolyzed to GDP by eIF5, and the initiation factors (eIF1, eIF2 and eIF5) bound to $40 \mathrm{~S}$ dissociate (Fig. 4). Then, joining of the $60 \mathrm{~S}$ large subunit mediated by eIF5B forms a 


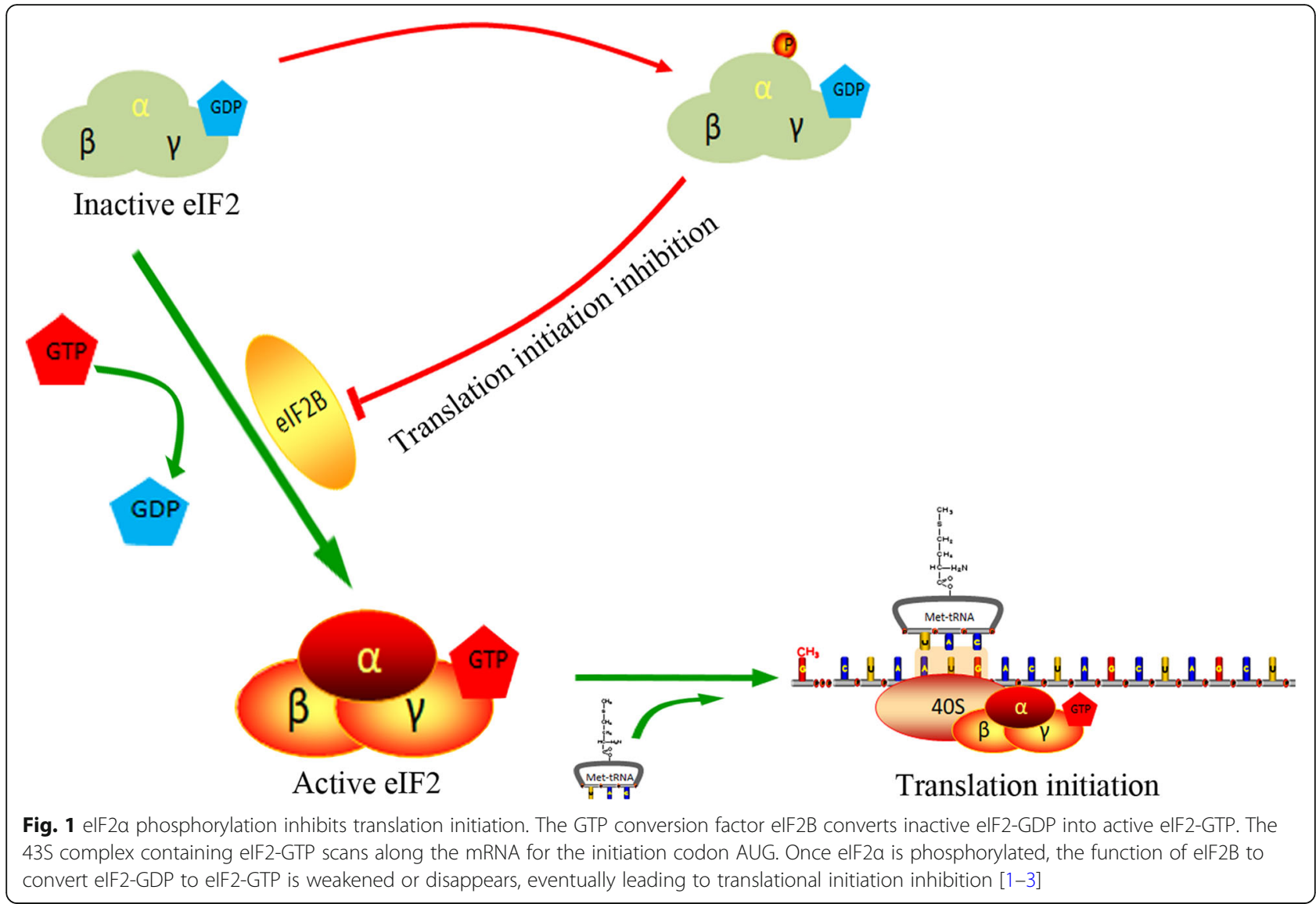

complete initiation complex with the 40S small subunit and begins peptide chain synthesis. eIF2 is a heterotrimer composed of $\alpha, \beta$ and $\gamma$ subunits, and its activity is regulated by phosphorylation of its $\alpha$ subunit at Ser51. Once eIF2 $\alpha$ is phosphorylated, the eIF2 affinity for eIF2B is increased, and the ability of eIF2B to convert eIF2GDP to eIF2-GTP is decreased or absent, resulting in GTP that cannot cycle, eventually inhibiting translational initiation [1-3]. In addition, the level of eIF2B in the cell is 10 to 20 times lower than that of eIF2; therefore, small changes in eIF2 phosphorylation can have a significant effect on protein translation [5].

Four kinases that phosphorylate eIF2 $\alpha$ have been identified in mammals, namely, general control nonderepressible-2 (GCN2), protein kinase R-like endoplasmic reticulum kinase (PERK), doublestranded RNA (dsRNA)-dependent protein kinase (PKR), and heme-regulated inhibitor (HRI) [6]. These four kinases are all Ser/Thr kinases that phosphorylate Ser51 of the eIF2 $\alpha$ subunit under different stress conditions, which weakens the eIF2 ability to bind GTP during translation, resulting in the general translation suppression. After viral invasion, eIF2 $\alpha$ phosphorylation is both advantageous and disadvantageous to cells: on the one hand, eIF $2 \alpha$ phosphorylation shuts down protein synthesis and prevents viral replication; on the other hand, prolonged eIF $2 \alpha$ phosphorylation leads to apoptosis or autophagy. In this paper, we discuss the role of eIF $2 \alpha$ in viral infection and provide a reference for studying the interactions between viruses and hosts and the development of possible new targeted drugs.

\section{Main text}

Viral infection and elF2a phosphorylation

The four host kinases mentioned above play different roles: PKR senses dsRNA during viral infection [7]; endoplasmic reticulum (ER) stress initiates the unfolded protein response (UPR) to activate PERK [8]; HRI monitors changes in hemoglobin levels $[9,10]$; and GCN2 detects amino acid starvation [11], UV damage, and viral infection [12]. The main downstream substrate of these four kinases is eIF2 $\alpha$, but other substrates of these kinases have also been discovered. For instance, PERK acts on nuclear factor erythroid 2-related factor 2 (Nrf2) [13, 14], while PKR acts on nuclear factor kappa-lightchain-enhancer of activated B cells (NF-kB) $[15,16]$ and the tumor suppressor gene P53 [17]. This wide range of kinase activity contributes to the ability of different eIF2 $\alpha$ kinases to sense different signals determined by 
unique regulatory characteristics. However, in some cases, the overlap of these stimuli leads to some redundancy between kinases [18]. After a virus invades the host cell, the host produces a corresponding stress response that stimulates stress kinases (GCN2, PKR, PERK, HRI), which affect eIF2 $\alpha$ phosphorylation. Among these kinases, GCN2 and PKR have antiviral effects in the viral infection process. PERK plays a role in ER stress caused by viral protein synthesis, and HRI may play a role in the viral infection process. The four kinases play important roles in coordination under stress. However, under continuous viral infection, the virus promotes its own replication by regulating different eIF $2 \alpha$ kinases.

\section{Viral infection and GCN2}

GCN2 activation, which occurs when cells lack essential amino acids, inhibits cellular protein translation $[19,20]$. Recent studies have shown that GCN2 also plays an important role in inhibiting viral infection. GCN2 is involved in the innate antiviral response pathway of the host defense against RNA viruses, and mice in which GCN2 has been knocked out are more susceptible to Sindbis virus (SINV) and have higher viral titers in their brain than normal mice [21]. Human immunodeficiency virus-1 (HIV-1) activates GCN2, and GCN2 inhibits HIV-1 viral replication [22]. Similarly, GCN2 also has a strong inhibitory effect on vesicular stomatitis virus (VSV) [23]. Although GCN2 can inhibit viruses, viruses can also regulate GCN2. For example, HIV-1 encodes a protease (HIV-1Pro) that cleaves the viral precursor polyprotein, which cleaves GCN2 and prevents its antiviral effect [22]. The K3L protein of vaccinia virus (VV) interacts directly with the kinase catalytic domain of GCN2, inhibiting GCN2 and the general amino acid control pathway [24].

\section{Viral infection and PERK}

During viral infection, viral proteins pressure the host ER, resulting in ER stress. Host cells respond to ER stress, initiate the UPR, and activate the stress sensor PERK, inositol-requiring enzyme 1 (IRE1) and activating transcription factor 6 (ATF6). When the cell is at rest, these three stress sensors bind to glucose-regulated protein 78 (GRP78), which is also called binding immunoglobulin protein (Bip). Bip dissociates from the stress sensors and activates them in the presence of accumulated unfolded proteins in the ER (Fig. 2) [34, 35]. Under ER stress, ATF6 is released from Bip and transported to the Golgi complex, where it is sequentially cleaved by two proteases, the site 1 and site 2 proteases (S1P and S2P), to form active p50 ATF6; active p50 ATF6 is then transported to the nucleus, where it activates the transcription of genes containing the ER stress response element (ERSE), such as Bip and XBP1 [25-27]. Activated IRE1 cleaves 26 nucleotides from
$\mathrm{XBP} 1 \mathrm{mRNA}$ to generate spliced XBP1 mRNA, which is translated to the active spliced XBP1 (XBP1(s)) protein. Subsequently, XBP1(s) activates the transcription of genes containing UPR elements (UPREs), such as ERdegradation-enhancing alpha-mannosidase-like protein-1 (EDEM1), which causes misfolded protein degradation [28-31]. Here, we focus on the importance of PERK in regulating ER stress and cell survival. This kinase phosphorylates the eIF2 $\alpha$ subunit and reduces protein synthesis to relieve ER stress [32, 33].

Most viruses stimulate the PERK-eIF2 $\alpha$ pathway after infecting host cells, and there have been many reports on this process. Porcine reproductive and respiratory syndrome virus (PRRSV) phosphorylates eIF2 $\alpha$ via a PERK-dependent mechanism and induces the formation of stress granules (SGs), which were shown to be involved in the PRRSV-induced inflammatory signaling pathway in MARC-145 cells [36]. In the late stage of PRRSV infection, PERK-mediated eIF $2 \alpha$ phosphorylation inhibits tumor necrosis factor alpha (TNF- $\alpha$ ) and interferon alpha (IFN- $\alpha$ ) production in alveolar macrophages [37]. Hepatitis $\mathrm{C}$ virus (HCV) is a classic ER stressinducing virus that activates three stressors and regulates this stress response [38-40]. The core protein and envelope proteins (E1 and E2) of HCV mature in the ER and are important proteins that cause ER stress [39-42]. However, HCV can modulate PERK kinase through the E1 and E2 proteins. E1 can interact with PERK, inhibit Bip and CHOP promoter activity and decrease CHOP expression induced by the UPR [40]. The E2 protein has a PKR-eIF2 $\alpha$ phosphorylation site homology domain (PePHD), which can mimic PERK's natural substrate eIF2 $\alpha$, thus reversing the translational repression induced by ER stress [39]. In addition, enterovirus 71 (EV71), porcine circovirus type 2 (PCV2), bluetongue virus type 1 (BTV1) and dengue virus (DENV) can also enhance replication using the PERK pathway [43-46]. PERK pathway activation increases $\mathrm{Ca} 2+$ and intracellular reactive oxygen species (ROS) levels in the cytosol and mitochondria to induce apoptosis [47].

\section{Viral infection and PKR}

The transcription of PKR, which has antiviral activity, is induced by IFN, and PKR is activated early in viral infection. In turn, IFN induction requires PKR catalytic activity, and PKR plays a role in the MDA5 signaling pathway [48]. PKR consists of an N-terminal dsRNAbinding domain (dsRBD) and a C-terminal kinase catalytic domain [49]. dsRNA produced during viral replication can bind the dsRBD at the N-terminus of PKR. dsRNA binding causes conformational changes that lead to dsRBD release from the kinase domain and induce PKR dimerization through the kinase domain and subsequent PKR phosphorylation [50]. Activated PKR inhibits 


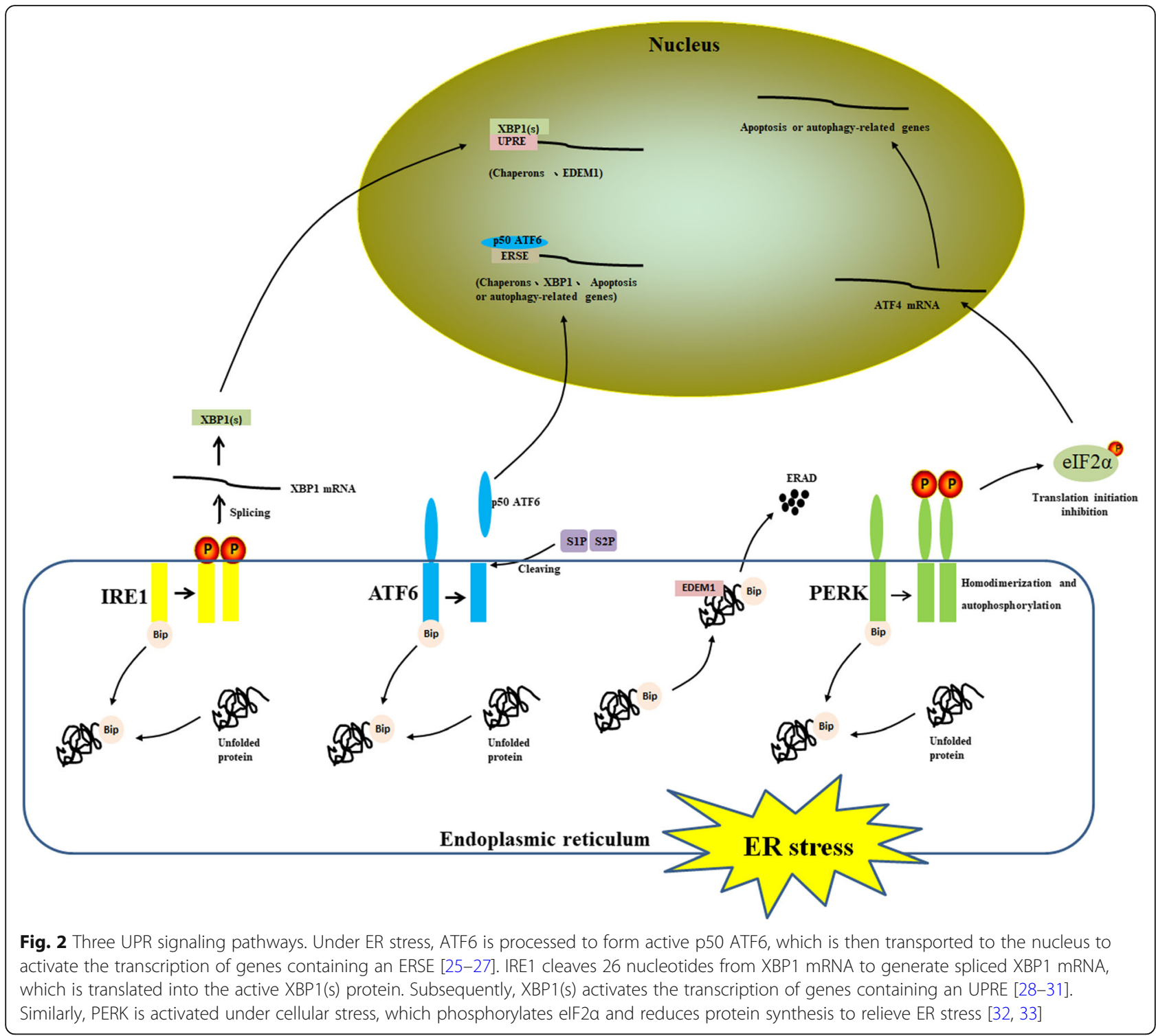

viral protein translation primarily by phosphorylating eIF $2 \alpha$ to achieve its antiviral effect.

Some viruses can use PKR activation to promote their replication. After the treatment of CHSE-214 and TO cells with the PKR inhibitor C16, infectious pancreatic necrosis virus (IPNV) induced reduced eIF2 $\alpha$ phosphorylation, and the viral titer was decreased, indicating that IPNV proliferation depends on PKR activation [51]. Similarly, in HCVinfected cells, $\mathrm{HCV}$ replicated more efficiently only when PKR was activated, and PKR activation inhibition reduced the amount of virus [52]. One reason for this finding is that the NS5B protein interacts with PKR, and its RNA polymerase activity activates PKR, resulting in the decreased major histocompatibility complex I (MHC-I) expression [53]. Another reason for these effects is that $\mathrm{HCV}$ nonstructural protein 5A (NS5A) can directly bind the PKR protein kinase catalytic domain, thereby inducing IFN resistance [54].

However, most viruses usually block the PKR antiviral effects in a variety of ways (Fig. 3). 1. Hiding dsRNA is one such strategy. A proline-rich structure on the RNAbinding protein (RBP) encoded by the Us11 gene of herpes simplex virus type 1 (HSV-1) inhibits PKR activation, and the RBP can bind viral dsRNA to avoid PKR recognition $[55,56]$. 2. Blocking PKR activation is another strategy. Encephalomyocarditis virus (EMCV), PRRSV, the NS1 protein of influenza A virus (IAV) and the accessory protein 4a of Middle East respiratory syndrome coronavirus (MERS-CoV) prevent PKR activation and the effects of eIF $2 \alpha$ phosphorylation on viral protein synthesis [57-61]. 3. Some viral factors act as a pseudosubstrate for PKR. The myxoma virus immunoregulatory 


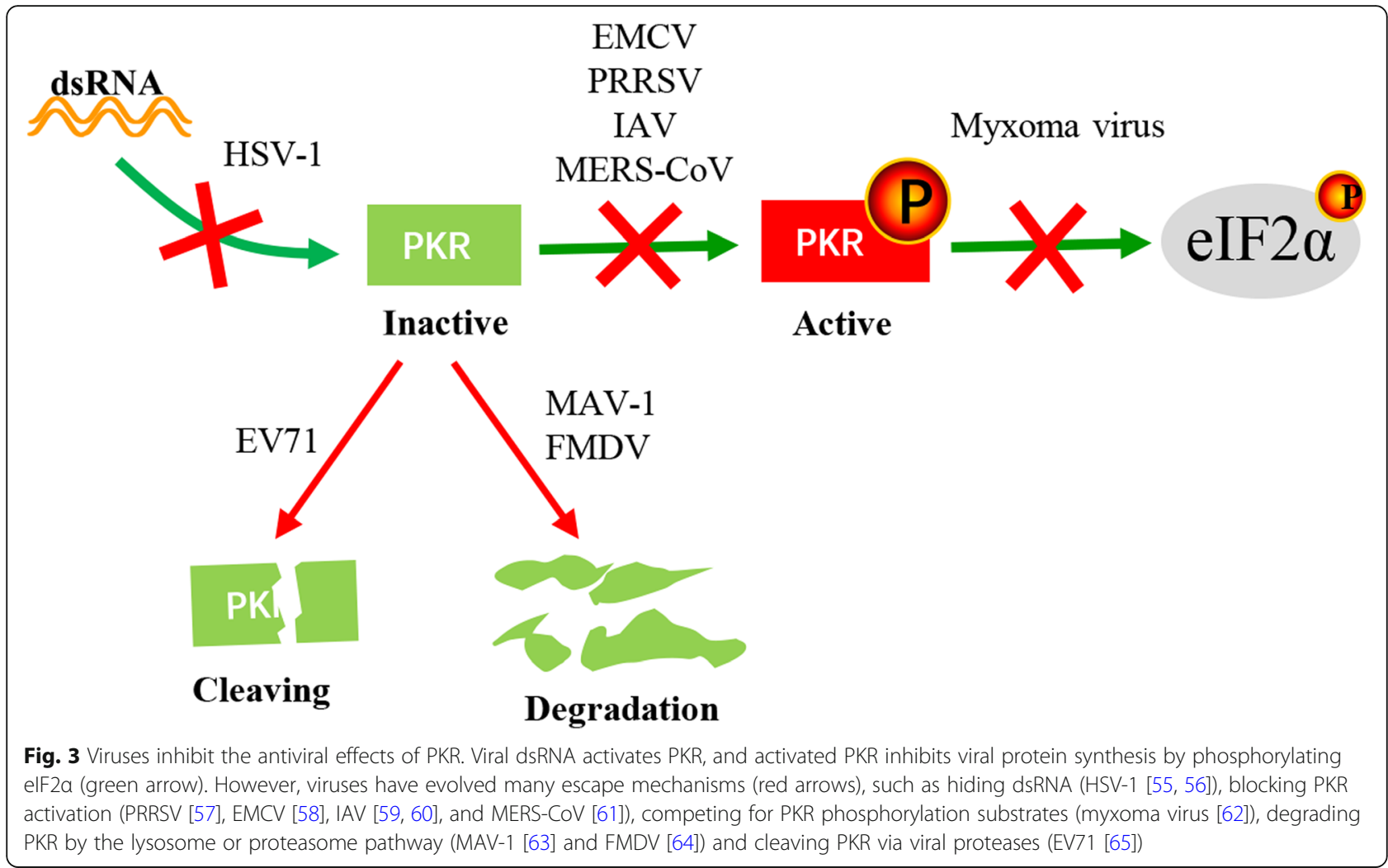

protein M156R, an effective PKR phosphorylation substrate, competes with eIF2 $\alpha$, alleviating the effect of PKR on viral protein synthesis [62]. 4. Other viruses degrade PKR by the lysosome or proteasome pathway. Mouse adenovirus type 1 (MAV-1) and foot-and-mouth disease virus (FMDV) degrade PKR via the proteasome pathway and lysosome pathway, respectively [63, 64]. 5. Another strategy is PKR cleavage by viral proteases. After EV71 infection, the $3 \mathrm{C}$ protein can cleave $\mathrm{PKR}$ at position Q188, resulting in decreased PKR expression [65].

\section{Viral infection and HRI}

HRI was originally thought to be mainly expressed in nucleated red blood cells, where it regulates protein synthesis and mature erythrocyte numbers. However, recent studies have shown that HRI is also present in the liver and phagocytic cells [66]. HRI is inactive at normal hemoglobin concentrations; once hemoglobin concentrations are reduced, HRI can be activated by autophosphorylation [10]. The HRI heme-binding site is located at its N-terminus and kinase insert domain [67], containing H119, H120 and C409, which are required for HRI function [10]. HRI is known to play a protective role when the host is infected with bacteria $[68,69]$, but there have been few reports on the role of HRI during infections in mammals. HRI is the only activated stress kinase in arsenite-treated L929 cells, and its activation increases the protein expression and infection rate of reovirus in cells after arsenite treatment $[70,71]$.

Recently, HRI was reported to be involved in the fish immune response to viral infections. Rong et al. detected HRI mRNA transcription and protein expression in Paralichthys olivaceus immune organs and tissues, and HRI transcription and translation in the P. olivaceus head kidney and spleen tissues infected with turbot Scophthalmus maximus L. rhabdovirus (SMRV) were significantly enhanced [72]. Overexpression of HRI homologs from the orange-spotted grouper inhibited redspotted grouper nervous necrosis virus (RGNNV) replication and increased IFN-associated cytokine levels [73].

\section{Effect of elF2a phosphorylation on viral replication elF2a phosphorylation regulates host cell and virus translation}

Classic translation initiation in eukaryotic cells is dependent on the ribosome scanning mechanism of the cap structure (Fig. 4). The process occurs as follows: $43 \mathrm{~S}$ preinitiation complex assembly, 43S preinitiation complex binding to mRNA, initiation codon (AUG) recognition, and $60 \mathrm{~S}$ ribosomal subunit addition to form a complete initiation complex and initiate translation [4]. After the virus invades cells, it can hijack or disturb PABP, eIF4G, eIF4E, eIF2, etc., which are involved in classic cap-dependent translation initiation, and reduce 


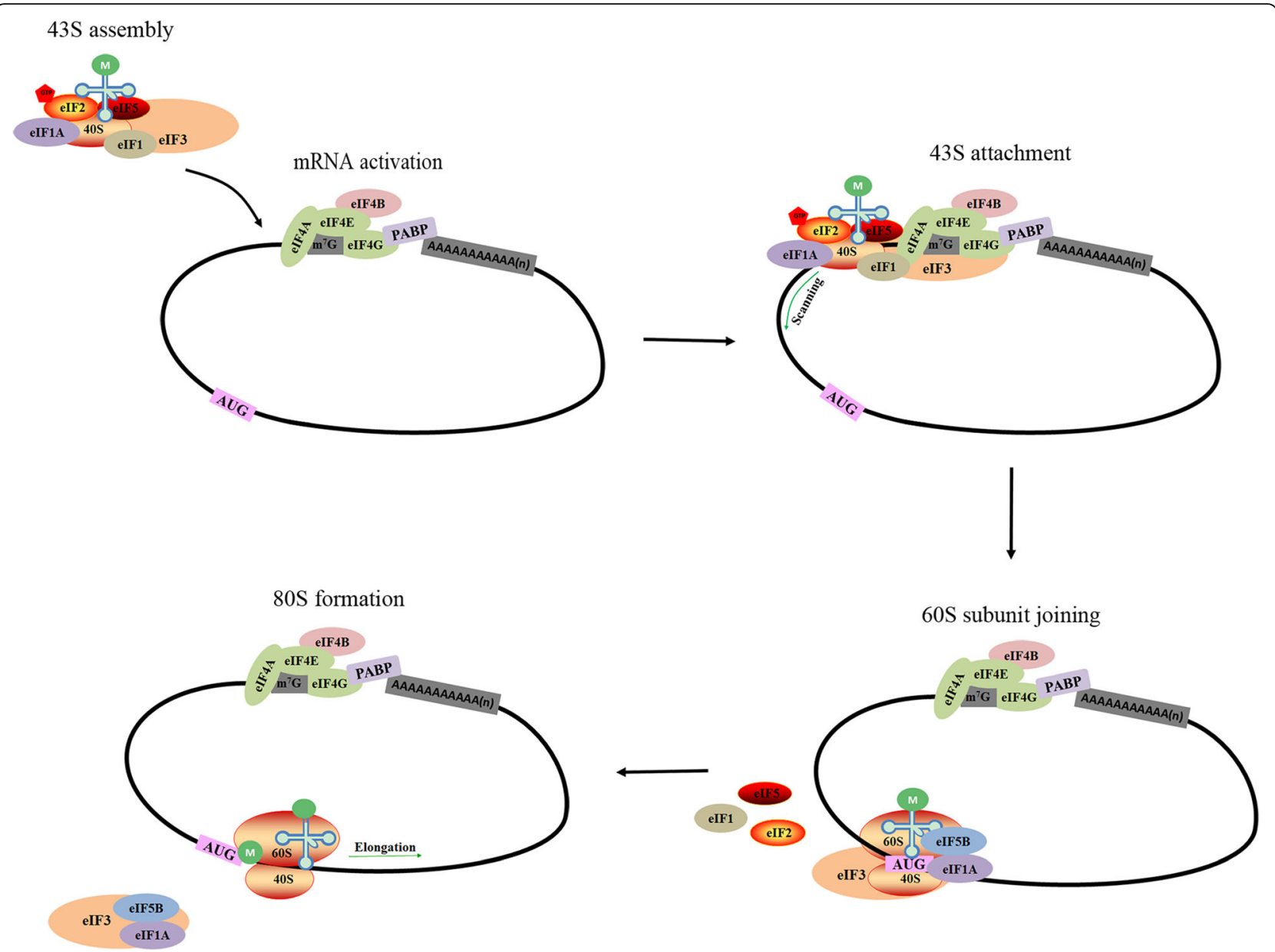

Fig. 4 Classical cap-dependent translation initiation in eukaryotic cells. The process consists of 435 preinitiation complex assembly, 435 preinitiation complex binding to mRNA, initiation codon (AUG) recognition, and 60S ribosomal subunit addition to form a complete initiation complex and start translation [4]

the efficiency of intracellular mRNA recruitment by ribosomes [74-77]. Among these factors, eIF2 $\alpha$ subunit phosphorylation disrupts $43 \mathrm{~S}$ subunit formation, leading to translation initiation cessation [78]. PRRSV infection induces host translational shutdown, which is associated with the C-terminal transmembrane (TM) region of viral nonstructural protein 2 (nsp2). PRRSV-induced host translational shutdown can be partially reversed by eIF2 $\alpha$ dephosphorylation or mTOR pathway reactivation, suggesting that both eIF2 $\alpha$ phosphorylation and mTOR signaling pathway attenuation contribute to PRRSV-induced host translational arrest [79]. However, not all viruses suppress ongoing host translation during their infection cycle [80]. For instance, the gamma [1] 34.5 protein of HSV-1 and the V16 and F18 residues in the African swine fever virus (ASFV) DP71L protein regulate protein phosphatase 1 (PP1) to dephosphorylate eIF $2 \alpha$, thereby avoiding general protein synthesis shutdown [81, 82]. Notably, DENV and MNV has been shown to trigger host cell translational shutdown uncoupled from eIF2 $\alpha$ phosphorylation in recent findings [83-85], which may be a new strategy for inhibiting host translation, and the mechanism for inhibiting host translation requires further study.

Differences in viral nucleic acids and their structures can lead to differences in their translation. The picornavirus genome does not have a $5^{\prime}$ cap structure but contains an internal ribosome entry site (IRES) sequence that can recruit a small ribosomal subunit to the viral mRNA translation initiation site with the help of some IRES-transacting factors (ITAFs) [86]. After coxsackievirus B type 3 (CVB3) enters the cell, it releases its viral nucleic acid and uses the host DAP5 protein to complete its first round of translation. Subsequently, the translated $2 \mathrm{~A}$ protein cleaves eIF4GI into two parts. The eIF4GI N-terminus is recruited to the IRES sequence, effectively promoting viral replication (Fig. 5a) [87]. However, picornavirus infection can cause eIF2 $\alpha$ phosphorylation, and translation may show a dual mechanism of eIF2 


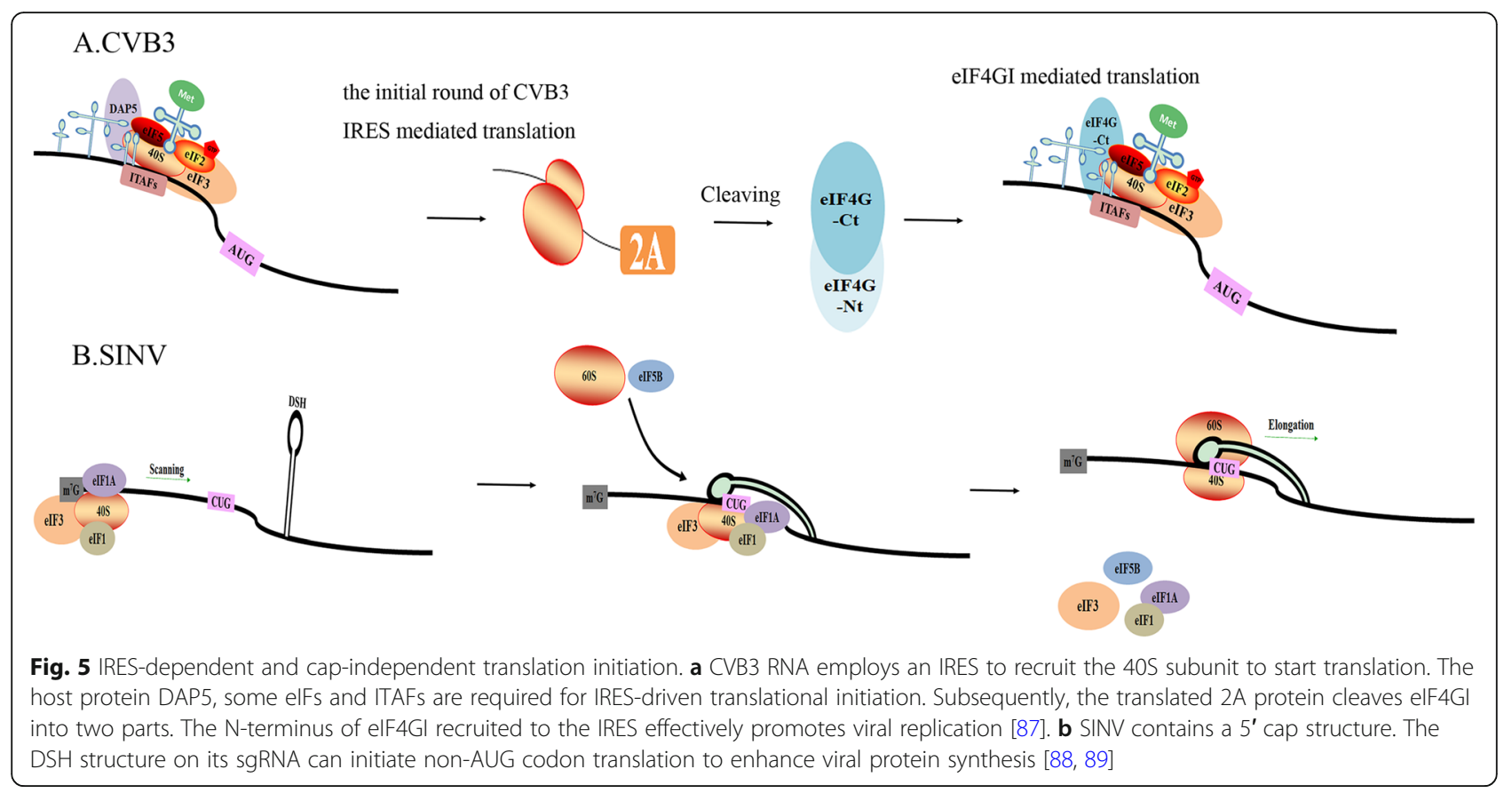

involvement: eIF2 $\alpha$ phosphorylation was shown to block EMCV RNA translation in the early infection stages, synthesizing the proteins necessary for genome replication, whereas in the late EMCV infection phase, viral protein synthesis could occur in the presence of eIF2 $\alpha$ phosphorylation [90]. In contrast, the SINV genome contains a $5^{\prime}$ cap structure. eIF $2 \alpha$ phosphorylation weakens the translational function of the host, which should be inhibited as host mRNAs contain a $5^{\prime}$ cap structure; however, SINV mRNAs are all efficiently translated after eIF2 $\alpha$ phosphorylation [91]. This phenomenon occurs because SINV subgenomic mRNA (sgRNA) has a downstream stable hairpin (DSH) structure located in the coding region, which facilitates non-AUG codon translation to enhance viral protein synthesis (Fig. 5b). The mutation of nucleotides on the DSH loop reduced translation initiation at the CUG codon, and DSH was shown to interact with the $40 \mathrm{~S}$ subunit to facilitate sgRNA translation $[88,89]$.

How host translation initiation factors are used to promote the synthesis of a virus's own proteins when eIF2 $\alpha$ is phosphorylated is a controversial issue. It is suspected that viruses can use proteins other than eIF2 to promote translation of their proteins. Terenin et al. suggested that eIF2 was replaced by eIF5B and eIF3 in HCV-infected cells and that Met-tRNAi ${ }^{\text {Met }}$ was transported to the small ribosomal subunit independently of eIF2-GTP, thereby initiating viral IRES translation [92]. Kim et al. hypothesized that eIF2A can replace eIF2 and bind the HCV IRES to guide translation [93]. Subsequent studies have suggested that $\mathrm{HCV}$ mRNA initiates translation using the ternary Met-tRNAi ${ }^{\text {Met }}$-eIF2-GTP complex under normal cellular conditions but does not rely on eIF2 under stress because the interaction of the HCV IRES with the preinitiation complex replaces its interaction with eIF2 [94]. However, recent studies have shown that eIF2, eIF2A, eIF2D, eIF4A, and eIF4G are not involved in HCV IRES-driven translation [95]. Therefore, a deeper understanding of the viral translation mechanism is required. Changes in translation mechanisms after viral infection may be better understood through proteomics.

Although viruses can induce host translational shutdown, they can selectively express host mRNA, allowing the host to better serve the virus [80]. eIF2A or eIF2D can be used to replace eIF2 in the expression of these mRNAs or initiate non-AUG codon translation under stressful conditions due to viral infection [96]. During $\mathrm{VV}$ infection, the relative translational efficiency of mRNAs involved in oxidative phosphorylation, which is responsible for cellular energy production, was increased, and the levels and activities of proteins involved in oxidative phosphorylation were increased, while cellular oxidative phosphorylation inhibition significantly inhibited VV replication [97]. The alphavirus nsP3 protein YXXM motif binds the phosphatidylinositol 3-kinase (PI3K) regulatory subunit p85 and protein kinase $\mathrm{B}$ (PKB or $\mathrm{AKT}$ ), increasing glucose metabolism toward fatty acid synthesis [98]. In addition, when eIF2 $\alpha$ was phosphorylated, the stress-related proteins ATF4 and CHOP could still be synthesized [99]. The role of the eIF2 $\alpha$-ATF4-CHOP pathway in the virus life cycle is discussed in a later section. 
elF2a phosphorylation leads to SG formation

SGs are formed under stress (heat shock, starvation, ultraviolet radiation, or viral infection) [100]. SG assembly is driven by liquid-liquid phase separation (LLPS), which occurs when the collective interactions of a core protein-RNA interaction network breach a saturation threshold under stress. Ras GTPase-activating proteinbinding protein 1 (G3BP1) is the central node of this network, which functions as a tunable switch to trigger RNA-dependent LLPS. Furthermore, G3BP1 can regulate the SG core network through positive or negative cooperativity with other G3BP1-binding factors [101].

The core component of SG formation is stalled preinitiation translation complex aggregation, including mRNA, the 40S ribosomal subunit, translation initiation factors and many RBPs [102]. G3BP1, T cell-restricted intracellular antigen 1 (TIA-1) and TIA-1-related protein (TIAR) are important RBPs in SGs. When cells adapt to stress or when the pressure is removed and the cells exhibit normal, balanced translation, SGs will disintegrate [103]. In some cases, SG formation is dependent on eIF $2 \alpha$ phosphorylation [104], and phosphorylated eIF $2 \alpha$ reduces the tRNAMet-GTP-eIF2 ternary complex activity level, which promotes TIA-1 transfer from the nucleus to the cytoplasm, where it binds the $48 \mathrm{~S}$ complex to replace the ternary complex; these effects thus promote polyribosome decomposition and simultaneous mRNA transfer to SGs [105]. Since SGs isolate cellular and viral mRNAs and translational initiation factors to inhibit viral translation during viral infection, they are antiviral structures.

SG formation provides a platform for antiviral signaling pathways [58]. In the viral infection process, SGs can recruit a variety of proteins related to innate immunity, such as PKR, 2' -5 ' oligoadenylate synthetase (OAS) and ribonuclease L (RNase L), to protect cells [106]. OASlike protein 1 (OASL1), an OAS family member, is one of the SG components during viral infection. It contributes to type I IFN expression by trapping viral RNAs in SGs and increases the sensitivity of innate immune receptors involved in dsRNA recognition in the early infection stages [107]. Therefore, viral RNA and protein levels were found to be significantly inhibited in the early CVB3 infection stage [108].

Viruses have also evolved the following mechanisms to regulate SGs and thus promote their survival (Table 1). 1 . Viruses change the cellular localizations of key proteins that make up SGs. The rotavirus VP2, NSP2 and NSP5 proteins can cause eIF2 $\alpha$ phosphorylation but prevent SG formation by changing the localizations of the cellular proteins that make up SGs, allowing viral mRNA translation [5]. Mouse norovirus (MNV) and Zika virus (ZIKV) can recruit SG-related proteins into viral replication complexes to proliferate efficiently [84, 109]. 2 . Viruses also cleave key proteins that make up SGs. This strategy is most common in picornaviruses. EV71 infection induces SG formation via the PKR-eIF2 $\alpha$ pathway, but these SGs differ from typical SGs in their morphology and composition [118]. Later studies demonstrated that the EV71 2A protease cleaves eIF4GI to isolate cellular mRNA, allowing the virus to induce atypical SG formation and facilitate viral translation [110]. Another study also demonstrated that enterovirus (EV) 2Apro could antagonize SGs and inhibit IFN- $\beta$ transcription [119]. However, Zhang et al. suggested that EV71 2Apro is a key viral component that triggers SG formation in the early infection stages. As infection progresses, SGs are destroyed due to G3BP1 cleavage mediated by the viral protease 3Cpro [111]. These seemingly contradictory results may be caused by different experimental methods. Similarly, the Theiler's murine encephalomyelitis virus (TMEV) and FMDV L proteins can inhibit SG formation [113, 120]. Recent studies have shown that the picornavirus $\mathrm{L}$ and $2 \mathrm{~A}$ proteins can interfere with

Table 1 Strategies of some viruses for inhibiting SG formation. Viruses have evolved the following strategies to regulate SGs and thus promote their survival

\begin{tabular}{|c|c|c|c|}
\hline Virus & Viral protein & Strategies for resisting SG formation & Reference \\
\hline Rotavirus & & Changes the cellular localization of TIA-1 and PABP & [5] \\
\hline MNV & & Recruits G3BP1 to the viral replication complex & [84] \\
\hline $\mathrm{ZIKV}$ & & Alters the cellular localization of HuR & [109] \\
\hline EV71 & $2 \mathrm{~A}$ & Cleaves elF4GI & [110] \\
\hline EV71 & $3 C$ & Cleaves G3BP1 & [111] \\
\hline PV & $3 C$ & Cleaves G3BP1 & [112] \\
\hline FMDV & L & Cleaves G3BP1 and G3BP2 & [113] \\
\hline EMCV & $3 C$ & Cleaves G3BP1 & [58] \\
\hline Picornavirus & $\mathrm{L}$ or $2 \mathrm{~A}$ & Interferes with the elF4GI-G3BP1 interaction & [114] \\
\hline HPIV3 & & Hides viral RNA & [115] \\
\hline HIV-1 & & Inhibits PKR and elF2a phosphorylation & {$[116,117]$} \\
\hline
\end{tabular}


the eIF4GI-G3BP1 interaction and block typical SG formation [114]. In addition, EMCV and poliovirus (PV) can inhibit SG formation by 3C-mediated cleavage of G3BP1 $[58,112]$. These results show that the picornavirus $\mathrm{L}, 2 \mathrm{~A}$ and $3 \mathrm{C}$ proteins are $\mathrm{SG}$ antagonist proteins. 3. Additionally, viruses hide their viral RNA. Human parainfluenza virus type 3 (HPIV3) induces SG formation by eIF $2 \alpha$ phosphorylation and hides its newly synthesized viral RNA in inclusion bodies (IBs) to escape the antiviral effect of SGs [115]. 4. Moreover, viruses reduce eIF $2 \alpha$ phosphorylation. The HIV-1 nucleocapsid (NC) interacts with the host dsRNA-binding protein Staufen1 to inhibit PKR and eIF2 $\alpha$ phosphorylation, thereby dissociating SGs and relieving translation shutdown to achieve viral production $[116,117]$.

\section{elF2a phosphorylation blocks the cell replication cycle}

The cell replication cycle is divided into three phases: the G0 phase at rest, the intermitotic phase (G1 phase, S phase, and G2 phase) and the mitosis phase (M phase). After a virus invades cells, it blocks the cell cycle. Some viruses block the cell cycle at the G/M phase [121, 122], while some viruses block the cell cycle at the G0/G1 phase. G0/G1 phase blockade is associated with eIF2 $\alpha$ phosphorylation [123]. Newcastle disease virus (NDV) infection activated the PERK-eIF2 $\alpha$-CHOP pathway in HeLa cells, downregulating cyclin D1 to arrest the cell cycle at the G0/G1 phase and providing a favorable environment for NDV replication [124]. The Muscovy duck reovirus (MDRV) P10.8 protein reduced cyclindependent kinase 2 (CDK2), cyclin-dependent kinase 4 (CDK4) and cyclin E expression in DF-1 cells via the PERK-eIF2 $\alpha$ pathway, arresting the cells in the G0/G1 phase [125]. The virus replication process requires a series of proteins in the host cell that facilitate its replication, and viral infection causes the cells to stagnate in the G0/G1 phase, reducing the competitive pressure due to intracellular DNA replication and providing an environment favorable for virus replication $[126,127]$.

\section{elF2a phosphorylation mediates cell autophagy or apoptosis}

Under stress, the host can regulate autophagy via the eIF2 $\alpha$ kinase signaling pathway [128]. Activating transcription factor 4 (ATF4) is preferentially translated during eIF $2 \alpha$ phosphorylation. ATF4 has two upstream open reading frames (uORFs) that regulate ATF4 translation (Fig. 6). uORF1 is a positive element that facilitates ribosome scanning and reinitiation at downstream coding regions in ATF4 mRNA, while uORF2 is an inhibitory element that blocks ATF4 expression. In nonstressed cells, uORF1 facilitates ribosome scanning and reinitiates at the downstream coding region, uORF2, which blocks ATF4 expression. Under stress conditions, the time required for scanning ribosomes to reinitiate translation increases; thus, uORF1 allows ribosomes to scan through uORF2 and to initiate the ATF4-coding region [129]. ATF4 regulates ATF4-specific target genes through heterodimerization or posttranslational modifications (ubiquitination, phosphorylation, acetylation, or methylation), and these target genes are involved in apoptosis or autophagy, the cell cycle, amino acid import and metabolism, and resistance to oxidative stress [130-137]. Therefore, ATF4 is the main stress regulator of cells, balancing the pro- and anti-survival of cells [138]. Here, we discuss that viral infection induces autophagy or apoptosis through the eIF $2 \alpha-\mathrm{ATF} 4$ pathway.

Under stress, the eIF2 $\alpha$-ATF4 pathway activates the transcription of a large number of autophagy genes (P62,

\section{A. High eIF2-GTP}

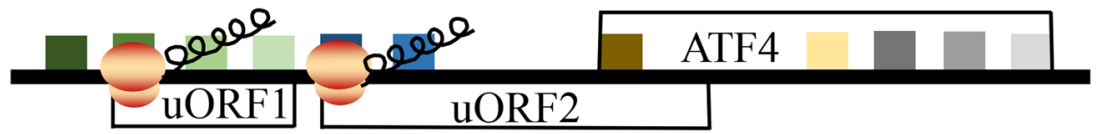

B. Low eIF2-GTP

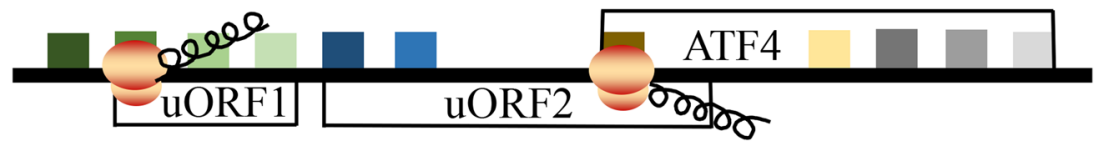

Fig. 6 The translation regulation of ATF4 under stress conditions. ATF4 translation is regulated through upstream open reading frames (uORFs). The 5'-proximal uORF1 encodes three amino acid residues, and the uORF2 and ATF4 coding regions partially overlap. In nonstressed cells, uORF1 facilitates ribosome scanning and reinitiates at the downstream coding region, uORF2, which blocks ATF4 expression. Under stress conditions, the time required for scanning ribosomes to reinitiate translation increases; thus, UORF1 allows ribosomes to scan through uORF2 and to initiate the ATF4-coding region [129] 
Atg1611, Map1lc3b, Atg12, Atg3, Becn1, Gabarapl2, etc.) [139]. Autophagy enables cells to recover amino acids and nutrients to maintain protein synthesis, energy synthesis and metabolic balance [140]. After viral invasion, autophagy can process and present antigens to MHCI and MHC-II molecules in order to activate adaptive immune responses [141-143]. However, the virus can regulate autophagy to facilitate its own replication [144-146]. The FMDV capsid protein VP2 was found to activate the eIF2 $\alpha$-ATF4 pathway and interact with heat shock protein beta-1 (HSPB1) to induce autophagy, while FMDV replication was significantly reduced when autophagy was suppressed [145]. Mammalian cell infection with HSV-1 induced autophagy via PKR-eIF2 $\alpha$, but this autophagy could be antagonized by the HSV-1 neurovirulence gene product ICP34.5 [128]. Virus-induced autophagy is often associated with ER stress. For example, DENV, CVB3, duck enteritis virus (DEV), prototype foamy virus (PFV) and other viruses induce autophagy through the PERK-eIF2 $\alpha$ pathway [44, 147-149].

CHOP, a key ATF4 downstream target, is also efficiently translated when eIF $2 \alpha$ is phosphorylated. It can be speculated that CHOP may have a translation regulation mechanism similar to that of ATF4. However, viral infection prolongs stress, and CHOP is involved in apoptosis. PCV2, the MDRV p10.8 protein and the Japanese encephalitis virus (JEV) NS4B protein promote apoptosis via the PERK-eIF2 $\alpha$-ATF4-CHOP pathway [46, 125, 150, 151]. Similarly, human astroviruses (HAstVs) activate caspase using the eIF2 $\alpha$-ATF4-CHOP pathway for viral release [152]. Interestingly, West Nile virus (WNV) proliferated to significantly higher viral titers in CHOPdeficient mouse embryonic fibroblasts (MEFs) than in wild-type MEFs, which indicates that $\mathrm{CHOP}$-mediated apoptosis functions to control WNV replication [153]. This finding shows that apoptosis has a dual role in viruses: on the one hand, apoptosis is beneficial for viral replication and release; on the other hand, apoptosis of host cells can inhibit viral spread to protect uninfected cells. Regarding the role of the latter, the virus can regulate CHOP expression for survival. The ASFV DP71L protein recruits PP1c to dephosphorylate eIF2 $\alpha$ and inhibit ATF4 and downstream CHOP, although the DP71L gene is not the only factor required for ASFV to control eIF2 $\alpha$ phosphorylation during infection [154]. The hepatitis B virus (HBV) X protein interacts directly with GRP78, inhibiting eIF2 $\alpha$ phosphorylation and subsequently inhibiting ATF4-CHOP-Bcl-2 expression to prevent hepatocellular carcinoma (HCC) cell death and the negative regulation of DNA repair [155].

$\mathrm{CHOP}$ can activate growth arrest and DNA damageinducible protein (GADD34) and PP1 to promote eIF2 $\alpha$ dephosphorylation and restore protein translation [156-158]. In the late NDV infection stage, eIF2 $\alpha$ phosphorylation leads to host cell translational shutdown, and GADD34

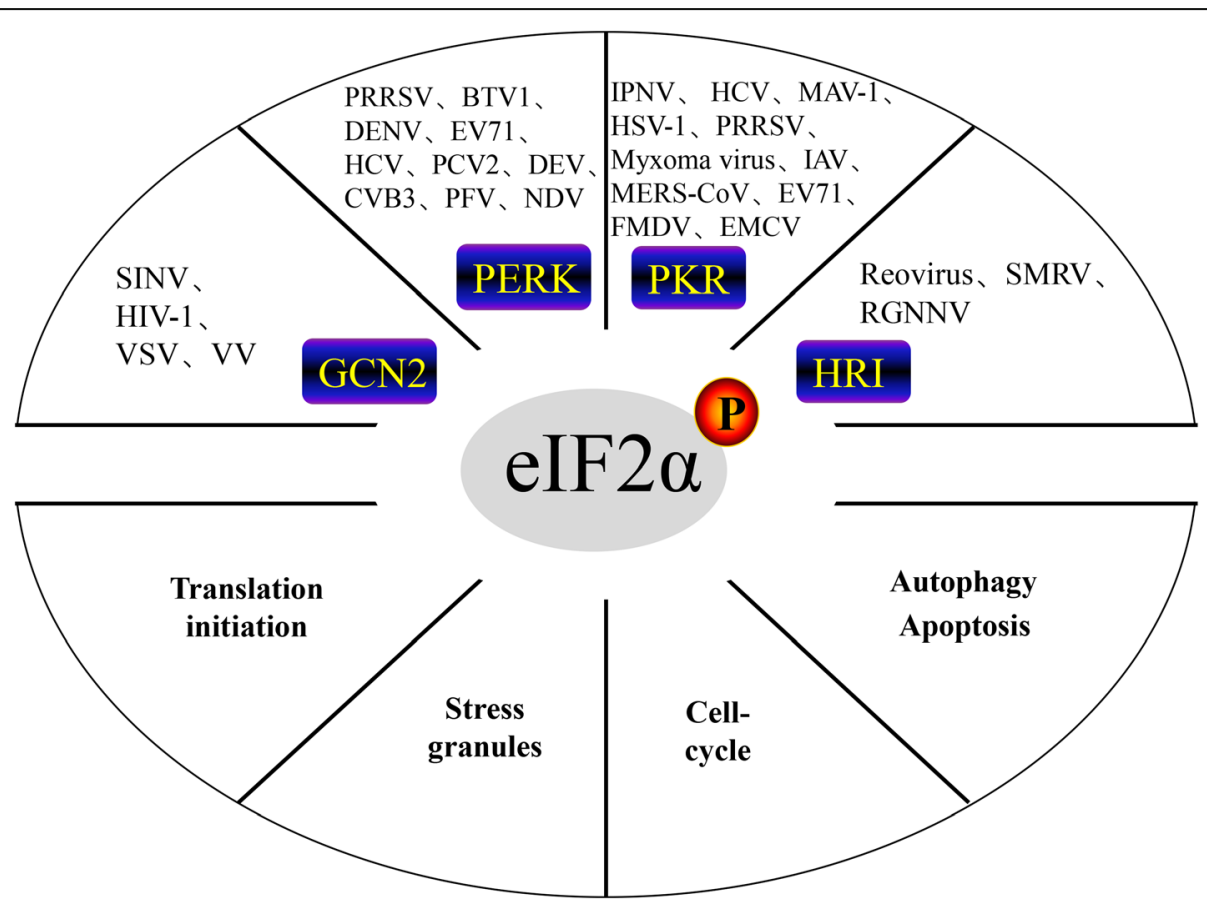

Fig. 7 The role of host elF2a in viral infection. Different viruses can stimulate specific elF2a kinases, or the same virus can stimulate different elF2a kinases, such as PRRSV, HCV, and EV71, which can activate PKR and PERK. elF2a phosphorylation can affect host cell translation efficiency, SG formation, the cell cycle, and autophagy or apoptosis, thus facilitating viral infection 
levels are upregulated, but PP1 downregulation counteracts the role of GADD34 [159]. The HSV $\gamma 34.5$ protein and the ASFV DP71L protein exhibit sequence similarity with GADD34, and PP1 recruitment dephosphorylates eIF2 $\alpha$ in infected cells, thereby promoting viral protein synthesis [160].

\section{Conclusion}

After viruses infect a host, they affect eIF2 $\alpha$ phosphorylation to promote self-replication. This process is manifested in main four ways (Fig. 7). First, the kinasepromoted eIF $2 \alpha$ phosphorylation inhibits host protein translation, and proteins beneficial to the virus itself are selectively expressed. Some viruses inhibit eIF $2 \alpha$ phosphorylation via GADD34 or PP1, avoiding host protein synthesis shutdown and promoting viral protein synthesis. Second, eIF2 $\alpha$ phosphorylation leads to SG formation, which encapsulate host and viral mRNAs and some translation initiation factors, but viruses can evade the antiviral effect of SGs in different ways, thereby promoting self-replication. Third, viruses use the PERK-eIF2 $\alpha$ CDK pathway to induce cell cycle arrest, providing a favorable environment for their replication. Fourth, viral infection leads to abnormal kinase expression, and autophagy or apoptosis is regulated by the eIF2 $\alpha$-ATF4 pathway to promote viral proliferation.

eIF $2 \alpha$, a balance point between cellular resistance to viruses and virus-induced apoptosis or autophagy, is essential for cell survival. Anne Bertolotti et al. found that the phosphatase regulatory subunit PPP1R15A (R15A) inhibitor Sephin1 could increase the eIF2 $\alpha$ phosphorylation level [161], and studies have shown that Sephin1 has inhibitory effects on some RNA and DNA viruses [162]. In addition, pathologic changes caused by viruses can induce cancerous changes in cells, such as HCC development in patients with HCV infection [163, 164]. Some studies have shown that eIF2 $\alpha$ phosphorylation inhibits c-Myc-mediated glycolysis, thereby inhibiting cancer growth and metastasis $[165,166]$. Therefore, the study of eIF $2 \alpha$ has played an important role in revealing viral pathogenesis and new targeted drug development. Simultaneously, how viruses synthesize their own proteins in the case of eIF $2 \alpha$ phosphorylation also needs to be further clarified systematically.

\section{Abbreviations}

GCN2: General control nonderepressible-2; PERK: Protein kinase R-like endoplasmic reticulum kinase; PKR: Protein kinase double-stranded RNAdependent; HRI: Heme-regulated inhibitor; mRNP: Messenger

ribonucleoprotein; SGs: Stress granules; elF: Eukaryotic initiation factor; ER: Endoplasmic reticulum; UPR: Unfolded protein response; Nrf2: Nuclear factor erythroid 2-related factor 2; NF-kB: Nuclear factor kappa-light-chain-enhancer of activated B cells; SV: Sindbis virus; HIV-1: Human immunodeficiency virus-1; VSV: Vesicular stomatitis virus; W: Vaccinia virus; IRE1: Inositolrequiring enzyme 1; ATF6: Activating transcription factors 6; GRP78: Glucoseregulated protein 78; Bip: Binding immunoglobulin protein; ERSE: ER stress response element; EDEM1: ER-degradation-enhancing alpha-mannosidase- like protein-1; PRRSV: Porcine reproductive and respiratory syndrome virus; TNF-a: Tumor necrosis factor alpha; IFN-a: Interferon alpha; BTV1: Bluetongue virus type 1; DENV: Dengue virus; EV71: Enterovirus 71; HCV: Hepatitis C virus; PePHD: PKR-elF2a phosphorylation site homology domain; PCV2: Porcine circovirus type 2; ROS: Reactive oxygen species; dsRBD: dsRNA-binding domain; IPNV: Infectious pancreatic necrosis virus; MAV-1: Mouse adenovirus type 1; HSV-1: Herpes simplex virus type 1; IAV: Influenza A virus; MERSCoV: Middle East respiratory coronavirus; FMDV: Foot-and-mouth disease virus; EMCV: Encephalomyocarditis virus; SMRV: Scophthalmus maximus L. rhabdovirus; RGNNV: Red-spotted grouper nervous necrosis virus; PP1: Protein phosphatase 1; ASFV: African swine fever virus; IRES: Internal ribosome entry site; ITAFs: IRES transacting factors; CVB3: Coxsackievirus B type 3; sgRNA: Subgenomic mRNA; DSH: Downstream stable hairpin; PI3K: Phosphatidylinositol 3-kinase; PKB or AKT: Protein kinase B; RBPs: RNAbinding proteins; G3BP1: Ras GTPase-activating protein-binding protein 1; TIA-1: T cell-restricted intracellular antigen 1; TIAR: TIA-1-related protein; OAS: 2'-5' oligoadenylate synthetase; RNase L: Ribonuclease L; RLR: Retinoic acid-inducible gene I-like receptor; MNV: Mouse norovirus; ZIKV: Zika virus; TMEV: Theiler's murine encephalomyelitis virus; PV: Poliovirus; HPIV3: Human parainfluenza virus type 3; IBs: Inclusion bodies; NDV: Newcastle disease virus; MDRV: Muscovy duck reovirus; CDK2: Cyclin-dependent kinase 2;

CDK4: Cyclin-dependent kinase 4; ATF4: Activating transcription factor 4; MHC-I: Major histocompatibility complex I; MHC-II: Major histocompatibility complex II; HSPB1: Heat shock protein beta-1; DEV: Duck enteritis virus; PFV: Prototype foamy virus; Bcl-2: B-cell lymphoma 2; HAstVs: Human astroviruses; JEV: Japanese encephalitis virus; HBV: Hepatitis B virus; HCC: Hepatocellular carcinoma; GADD34: Growth arrest and DNA damageinducible protein

\section{Acknowledgments}

Not applicable.

\section{Authors' contributions}

Yuanzhi Liu conceived, designed, and wrote the manuscript; Mingshu Wang, Anchun Cheng, Qiao Yang, Ying Wu, Renyong Jia, Mafeng Liu, Dekang Zhu, Shun Chen, Shaqiu Zhang, Xin-Xin Zhao, Juan Huang, Sai Mao, Xumin Ou, and Qun Gao revised the manuscript; Yin Wang, Zhiwen Xu, Zhengli Chen, Ling Zhu, Qihui Luo, Yunya Liu, Yanling Yu, Ling Zhang, Bin Tian, Leichang Pan, Mujeeb Ur Rehman and Xiaoyue Chen helped with the manuscript; all authors read and approved the final manuscript for publication.

\section{Funding}

This work was supported by the National Key Research and Development Program of China (2017YFD0500800), the China Agricultural Research System (CARS-42-17), and the Sichuan Veterinary Medicine and Drug Innovation Group of China Agricultural Research System (CARS-SVDIP).

\section{Availability of data and materials}

Not applicable.

Ethics approval and consent to participate Not applicable.

Consent for publication

Not applicable.

\section{Competing interests}

The authors declare that they have no competing interest.

\section{Author details}

${ }^{1}$ Institute of Preventive Veterinary Medicine, Sichuan Agricultural University, Wenjiang, Chengdu City, Sichuan 611130, P.R. China. ${ }^{2}$ Key Laboratory of Animal Disease and Human Health of Sichuan Province, Sichuan Agricultural University, Wenjiang, Chengdu City, Sichuan 611130, P.R. China. ${ }^{3}$ Avian Disease Research Center, College of Veterinary Medicine, Sichuan Agricultural University, Wenjiang, Chengdu City, Sichuan 611130, P.R. China. 
Received: 26 March 2020 Accepted: 23 June 2020

Published online: 23 July 2020

\section{References}

1. Asano K, Clayton J, Shalev A, Hinnebusch AG. A multifactor complex of eukaryotic initiation factors, elF1, elF2, elF3, elF5, and initiator tRNA(Met) is an important translation initiation intermediate in vivo. Genes Dev. 2000; 14(19):2534-46.

2. Sudhakar A, Ramachandran A, Ghosh S, Hasnain SE, Kaufman RJ, Ramaiah KV. Phosphorylation of serine 51 in initiation factor 2 alpha (elF2 alpha) promotes complex formation between elF2 alpha(P) and elF2B and causes inhibition in the guanine nucleotide exchange activity of elF2B. Biochemistry. 2000;39(42):12929-38.

3. Pavitt GD, Ron D. New insights into translational regulation in the endoplasmic reticulum unfolded protein response. Cold Spring Harb Perspect Biol. 2012;4(6):1-9.

4. Haimov O, Sinvani H, Dikstein R. Cap-dependent, scanning-free translation initiation mechanisms. Biochim Biophys Acta. 2015;1849(11):1313-8.

5. Montero H, Rojas M, Arias CF, López S. Rotavirus infection induces the phosphorylation of elF2alpha but prevents the formation of stress granules. J Virol. 2008;82(3):1496-504

6. Dever TE. Gene-specific regulation by general translation factors. Cell. 2002; 108(4):545-56

7. Galluzzi L, Brenner C, Morselli E, Touat Z, Kroemer G. Viral control of mitochondrial apoptosis. PLoS Pathog. 2008;4(5):e1000018.

8. Harding HP, Zhang Y, Ron D. Protein translation and folding are coupled by an endoplasmic-reticulum-resident kinase. Nature. 1999;397(6716):271-4.

9. Zhang S, Macias-Garcia A, Velazquez J, Paltrinieri E, Kaufman RJ, Chen JJ. HRI coordinates translation by elF2aP and mTORC1 to mitigate ineffective erythropoiesis in mice during iron deficiency. Blood. 2018;131(4):450-61.

10. Igarashi J, Murase M, lizuka A, Pichierri F, Martinkova M, Shimizu T. Elucidation of the heme binding site of heme-regulated eukaryotic initiation factor 2alpha kinase and the role of the regulatory motif in heme sensing by spectroscopic and catalytic studies of mutant proteins. J Biol Chem. 2008:283(27):18782-91

11. Deval C, Chaveroux C, Maurin AC, Cherasse Y, Parry L, Carraro V, et al. Amino acid limitation regulates the expression of genes involved in several specific biological processes through GCN2-dependent and GCN2independent pathways. FEBS J. 2009:276(3):707-18.

12. Yamasaki $S$, Anderson P. Reprogramming mRNA translation during stress. Curr Opin Cell Biol. 2008:20(2):222-6.

13. Cullinan SB, Zhang D, Hannink M, Arvisais E, Kaufman RJ, Diehl JA. Nrf2 is a direct PERK substrate and effector of PERK-dependent cell survival. Mol Cell Biol. 2003;23(20):7198-209.

14. Huang T, Zhao J, Guo D, Pang H, Zhao Y, Song J. Curcumin mitigates axonal injury and neuronal cell apoptosis through the PERK/Nrf2 signaling pathway following diffuse axonal injury. Neuroreport. 2018;29(8):661-77.

15. Li Y, Xiao J, Tan Y, Wang J, Zhang Y, Deng X, et al. Inhibition of PKR ameliorates lipopolysaccharide-induced acute lung injury by suppressing NF-KB pathway in mice. Immunopharmacol Immunotoxicol. 2017:39(4): $165-72$.

16. Yoshida K, Okamura H, Hiroshima $Y$, Abe K, Kido Jl, Shinohara $Y$, et al. PKR induces the expression of NLRP3 by regulating the NF-KB pathway in Porphyromonas gingivalis-infected osteoblasts. Exp Cell Res. 2017. 354(1):57-64.

17. Song $Y$, Wan $X$, Gao L, Pan $Y$, Xie W, Wang H, et al. Activated PKR inhibits pancreatic $\beta$-cell proliferation through sumoylation-dependent stabilization of P53. Mol Immunol. 2015;68(2 Pt A):341-9.

18. Donnelly N, Gorman AM, Gupta S, Samali A. The elF2a kinases: their structures and functions. Cell Mol Life Sci. 2013:70(19):3493-511.

19. Dever TE, Feng L, Wek RC, Cigan AM, Donahue TF, Hinnebusch AG. Phosphorylation of initiation factor 2 alpha by protein kinase GCN2 mediates gene-specific translational control of GCN4 in yeast. Cell. 1992; 68(3):585-96.

20. Zhang P, McGrath BC, Reinert J, Olsen DS, Lei L, Gill S, et al. The GCN2 elF2alpha kinase is required for adaptation to amino acid deprivation in mice. Mol Cell Biol. 2002;22(19):6681-8.

21. Berlanga JJ, Ventoso I, Harding HP, Deng J, Ron D, Sonenberg N, et al. Antiviral effect of the mammalian translation initiation factor 2alpha kinase GCN2 against RNA viruses. EMBO J. 2006;25(8):1730-40.
22. del Pino J, Jiménez JL, Ventoso I, Castelló A, Muñoz-Fernández M, de Haro $C$, et al. GCN2 has inhibitory effect on human immunodeficiency virus-1 protein synthesis and is cleaved upon viral infection. PLoS One. 2012;7(10): e47272.

23. Krishnamoorthy J, Mounir Z, Raven JF, Koromilas AE. The elF2alpha kinases inhibit vesicular stomatitis virus replication independently of elF2alpha phosphorylation. Cell Cycle. 2008;7(15):2346-51.

24. Qian W, Zhu S, Sobolev AY, Wek RC. Expression of vaccinia virus K3L protein in yeast inhibits eukaryotic initiation factor-2 kinase GCN2 and the general amino acid control pathway. J Biol Chem. 1996;271(22):13202-7.

25. Nakajima S, Hiramatsu N, Hayakawa K, Saito Y, Kato H, Huang T, et al. Selective abrogation of BiP/GRP78 blunts activation of NF-KB through the ATF6 branch of the UPR: involvement of C/EBP $\beta$ and mTOR-dependent dephosphorylation of Akt. Mol Cell Biol. 2011;31(8):1710-8.

26. Ye J, Rawson RB, Komuro R, Chen X, Davé UP, Prywes $R$, et al. ER stress induces cleavage of membrane-bound ATF6 by the same proteases that process SREBPs. Mol Cell. 2000;6(6):1355-64.

27. Chen X, Shen J, Prywes R. The luminal domain of ATF6 senses endoplasmic reticulum (ER) stress and causes translocation of ATF6 from the ER to the Golgi. J Biol Chem. 2002;277(15):13045-52.

28. Zhang $\mathrm{L}$, Chen $\mathrm{H}$, Brandizzi F, Verchot J, Wang A. The UPR branch IRE1bZIP60 in plants plays an essential role in viral infection and is complementary to the only UPR pathway in yeast. PLoS Genet. 2015;11(4): e1005164.

29. van der Harg JM, van Heest JC, Bangel FN, Patiwael S, van Weering JR, Scheper W. The UPR reduces glucose metabolism via IRE1 signaling. Biochim Biophys Acta Mol Cell Res. 2017;1864(4):655-65.

30. Lee AH, Iwakoshi NN, Glimcher LH. XBP-1 regulates a subset of endoplasmic reticulum resident chaperone genes in the unfolded protein response. Mol Cell Biol. 2003:23(21):7448-59.

31. Hosokawa N, Wada I, Hasegawa K, Yorihuzi T, Tremblay LO, Herscovics A, et al. A novel ER alpha-mannosidase-like protein accelerates ER-associated degradation. EMBO Rep. 2001;2(5):415-22.

32. Fels DR, Koumenis C. The PERKelF2alpha/ATF4 module of the UPR in hypoxia resistance and tumor growth. Cancer Biol Ther. 2006;5(7):723-8.

33. Harding HP, Zhang Y, Bertolotti A, Zeng H, Ron D. Perk is essential for translational regulation and cell survival during the unfolded protein response. Mol Cell. 2000:5(5):897-904.

34. Bertolotti A, Zhang Y, Hendershot LM, Harding HP, Ron D. Dynamic interaction of BiP and ER stress transducers in the unfolded-protein response. Nat Cell Biol. 2000;2(6):326-32.

35. Shen J, Chen $X$, Hendershot $L$, Prywes R. ER stress regulation of ATF6 localization by dissociation of BiP/GRP78 binding and unmasking of Golgi localization signals. Dev Cell. 2002:3(1):99-111.

36. Zhou Y, Fang L, Wang D, Cai K, Chen H, Xiao S. Porcine reproductive and respiratory syndrome virus infection induces stress granule formation depending on protein kinase R-like endoplasmic reticulum kinase (PERK) in MARC-145 cells. Front Cell Infect Microbiol. 2017;7:111.

37. Chen WY, Schniztlein WM, Calzada-Nova G, Zuckermann FA. Genotype 2 strains of porcine reproductive and respiratory syndrome virus dysregulate alveolar macrophage cytokine production via the unfolded protein response. J Virol. 2018;92(2):01251-17.

38. Asselah T, Bièche I, Mansouri A, Laurendeau I, Cazals-Hatem D, Feldmann G, et al. In vivo hepatic endoplasmic reticulum stress in patients with chronic hepatitis C. J Pathol. 2010;221(3):264-74.

39. Pavio N, Romano PR, Graczyk TM, Feinstone SM, Taylor DR. Protein synthesis and endoplasmic reticulum stress can be modulated by the hepatitis $\mathrm{C}$ virus envelope protein E2 through the eukaryotic initiation factor 2alpha kinase PERK. J Virol. 2003;77(6):3578-85.

40. Egan PA, Sobkowiak M, Chan SW. Hepatitis C virus envelope protein E1 binds PERK and represses the unfolded protein response. Open Virol J. 2013; 7:37-40.

41. Santolini E, Migliaccio G, La Monica N. Biosynthesis and biochemical properties of the hepatitis C virus core protein. J Virol. 1994;68(6): 3631-41.

42. Benali-Furet NL, Chami M, Houel L, De Giorgi F, Vernejoul F, Lagorce D, et al. Hepatitis $C$ virus core triggers apoptosis in liver cells by inducing ER stress and ER calcium depletion. Oncogene. 2005;24(31):4921-33.

43. Lv S, Sun EC, Xu QY, Zhang JK, Wu DL. Endoplasmic reticulum stressmediated autophagy contributes to bluetongue virus infection via the PERK-elF2a pathway. Biochem Biophys Res Commun. 2015;466(3):406-12. 
44. Lee YR, Kuo SH, Lin CY, Fu PJ, Lin YS, Yeh TM, et al. Dengue virus-induced ER stress is required for autophagy activation, viral replication, and pathogenesis both in vitro and in vivo. Sci Rep. 2018;8(1):489.

45. Jheng JR, Lau KS, Tang WF, Wu MS, Horng JT. Endoplasmic reticulum stress is induced and modulated by enterovirus 71. Cell Microbiol. 2010;12(6):796813.

46. Zhou Y, Qi B, Gu Y, Xu F, Du H, Li X, et al. Porcine circovirus 2 deploys PERK pathway and GRP78 for its enhanced replication in PK-15 cells. Viruses. 2016:8(2):56.

47. Zhang Y, Sun R, Geng S, Shan Y, Li X, Fang W. Porcine circovirus type 2 induces ORF3-independent mitochondrial apoptosis via PERK activation and elevation of cytosolic calcium. J Virol. 2019;93(7):e01784-18.

48. Pham AM, Santa Maria FG, Lahiri T, Friedman E, Marié IJ, Levy DE. PKR transduces MDA5-dependent signals for type I IFN induction. PLoS Pathog. 2016;12(3):e1005489.

49. Williams BR. PKR; a sentinel kinase for cellular stress. Oncogene. 1999;18(45): 6112-20.

50. Cole JL. Activation of PKR: an open and shut case? Trends Biochem Sci. 2007:32(2):57-62.

51. Gamil AA, Xu C, Mutoloki S, Evensen $\varnothing$. PKR activation favors infectious pancreatic necrosis virus replication in infected cells. Viruses. 2016;8(6):173.

52. Arnaud N, Dabo S, Maillard P, Budkowska A, Kalliampakou Kl, Mavromara P, et al. Hepatitis $C$ virus controls interferon production through PKR activation. PLoS One. 2010;5(5):e10575.

53. Suzuki R, Matsuda M, Shimoike T, Watashi K, Aizaki H, Kato T, et al. Activation of protein kinase $R$ by hepatitis C virus RNA-dependent RNA polymerase. Virology. 2019;529:226-33.

54. Gale MJ Jr, Korth MJ, Tang NM, Tan SL, Hopkins DA, Dever TE, et al. Evidence that hepatitis $C$ virus resistance to interferon is mediated through repression of the PKR protein kinase by the nonstructural 5A protein. Virology. 1997;230(2):217-27.

55. Poppers J, Mulvey M, Khoo D, Mohr I. Inhibition of PKR activation by the proline-rich RNA binding domain of the herpes simplex virus type 1 Us 11 protein. J Virol. 2000;74(23):11215-21.

56. Khoo D, Perez C, Mohr I. Characterization of RNA determinants recognized by the arginine- and proline-rich region of Us11, a herpes simplex virus type 1-encoded double-stranded RNA binding protein that prevents PKR activation. J Virol. 2002;76(23):11971-81.

57. Xiao Y, Ma Z, Wang R, Yang L, Nan Y, Zhang YJ. Downregulation of protein kinase PKR activation by porcine reproductive and respiratory syndrome virus at its early stage infection. Vet Microbiol. 2016;187:1-7.

58. Ng CS, Jogi M, Yoo JS, Onomoto K, Koike S, Iwasaki T, et al. Encephalomyocarditis virus disrupts stress granules, the critical platform for triggering antiviral innate immune responses. J Virol. 2013;87(17):9511-22.

59. Li S, Min JY, Krug RM, Sen GC. Binding of the influenza A virus NS1 protein to PKR mediates the inhibition of its activation by either PACT or doublestranded RNA. Virology. 2006:349(1):13-21.

60. Schierhorn KL, Jolmes F, Bespalowa J, Saenger S, Peteranderl C, Dzieciolowski J, et al. Influenza A virus virulence depends on two amino acids in the N-terminal domain of its NS1 protein to facilitate inhibition of the RNA-dependent protein kinase PKR. J Virol. 2017;91(10):e00198-17.

61. Rabouw HH, Langereis MA, Knaap RC, Dalebout TJ, Canton J, Sola I, et al. Middle East respiratory coronavirus accessory protein 4a inhibits PKRmediated antiviral stress responses. PLoS Pathog. 2016;12(10):e1005982.

62. Ramelot TA, Cort JR, Yee AA, Liu F, Goshe MB, Edwards AM, et al. Myxoma virus immunomodulatory protein M156R is a structural mimic of eukaryotic translation initiation factor elF2alpha. J Mol Biol. 2002;322(5):943-54.

63. Goodman DE, Pretto CD, Krepostman TA, Carnahan KE, Spindler KR. Enhanced replication of mouse adenovirus type 1 following virus-induced degradation of protein kinase R (PKR). mBio. 2019;10(2):e00668-19.

64. Li C, Zhu Z, Du X, Cao W, Yang F, Zhang X, et al. Foot-and-mouth disease virus induces lysosomal degradation of host protein kinase PKR by $3 C$ proteinase to facilitate virus replication. Virology. 2017;509:222-31.

65. Chang YH, Lau KS, Kuo RL, Horng JT. dsRNA binding domain of PKR is proteolytically released by enterovirus $A 71$ to facilitate viral replication. Front Cell Infect Microbiol. 2017;7:284.

66. Wang L, Zhang S, Wang Z, Xu M, Yuan L, Cui J, et al. A protective role of Heme-regulated elF2a kinase in cadmium-induced liver and kidney injuries. Chemosphere. 2017;185:284-9.

67. Rafie-Kolpin M, Chefalo PJ, Hussain Z, Hahn J, Uma S, Matts RL, et al. Two heme-binding domains of heme-regulated eukaryotic initiation factor- 2alpha kinase. $\mathrm{N}$ terminus and kinase insertion. J Biol Chem. 2000;275(7): 5171-8.

68. Shrestha N, Boucher J, Bahnan W, Clark ES, Rosqvist R, Fields KA, et al. The host-encoded Heme Regulated Inhibitor (HRI) facilitates virulence-associated activities of bacterial pathogens. PLoS One. 2013;8(7):e68754.

69. Bahnan W, Boucher JC, Gayle P, Shrestha N, Rosen M, Aktas B, et al. The elF2a kinase heme-regulated inhibitor protects the host from infection by regulating intracellular pathogen trafficking. Infect Immun. 2018;86(3): e00707-17.

70. McEwen E, Kedersha N, Song B, Scheuner D, Gilks N, Han A, et al. Hemeregulated inhibitor kinase-mediated phosphorylation of eukaryotic translation initiation factor 2 inhibits translation, induces stress granule formation, and mediates survival upon arsenite exposure. J Biol Chem. 2005; 280(17):16925-33.

71. Lutz MM, Worth MP, Hinchman MM, Parker JSL, Ledgerwood ED. Mammalian orthoreovirus infection is enhanced in cells pre-treated with sodium arsenite. Viruses. 2019;11(6):e563.

72. Zhu R, Zhang YB, Zhang QY, Gui JF. Preparation of polyclonal antibody and virus-induced tissue expression of Paralichthys olivaceu HRI. Acta Hydrobiologica Sinica. 2007;31(1):119-24.

73. Zang S, Zhang X, Li C, Wang L, Wei J, Qin Q. HRI of Epinephelus coioides is a critical factor in the grouper immune response to RGNNV infection. Fish Shellfish Immunol. 2019;87:659-68.

74. Kobayashi M, Arias C, Garabedian A, Palmenberg AC, Mohr I. Site-specific cleavage of the host poly $(A)$ binding protein by the encephalomyocarditis virus 3C proteinase stimulates viral replication. J Virol. 2012;86(19):10686-94.

75. Sun D, Wang M, Wen X, Cheng A, Jia R, Sun K, et al. Cleavage of poly(A)binding protein by duck hepatitis A virus 3C protease. Sci Rep. 2017;7(1): 16261.

76. Castelló A, Franco D, Moral-López P, Berlanga JJ, Alvarez E, Wimmer E, et al. HIV- 1 protease inhibits Cap- and poly(A)-dependent translation upon elF4GI and PABP cleavage. PLoS One. 2009:4(11):e7997.

77. Gingras AC, Svitkin Y, Belsham GJ, Pause A, Sonenberg N. Activation of the translational suppressor 4E-BP1 following infection with encephalomyocarditis virus and poliovirus. Proc Natl Acad Sci U S A. 1996; 93(11):5578-83.

78. Kimball SR. Eukaryotic initiation factor elF2. Int J Biochem Cell Biol. 1999; 31(1):25-9.

79. Li Y, Fang L, Zhou Y, Tao R, Wang D, Porcine Reproductive XS. Respiratory syndrome virus infection induces both elF2a phosphorylation-dependent and -independent host translation shutoff. J Virol. 2018;92(16):e00600-18.

80. Stern-Ginossar N, Thompson SR, Mathews MB, Mohr I. Translational control in virus-infected cells. Cold Spring Harb Perspect Biol. 2019;11(3):a033001.

81. He B, Gross M, Roizman B. The gamma(1)34.5 protein of herpes simplex virus 1 complexes with protein phosphatase 1alpha to dephosphorylate the alpha subunit of the eukaryotic translation initiation factor 2 and preclude the shutoff of protein synthesis by double-stranded RNA-activated protein kinase. Proc Natl Acad Sci U S A. 1997;94(3):843-8.

82. Barber C, Netherton C, Goatley L, Moon A, Goodbourn S, Dixon L. Identification of residues within the African swine fever virus DP71L protein required for dephosphorylation of translation initiation factor elF2a and inhibiting activation of pro-apoptotic CHOP. Virology. 2017;504:107-13.

83. Roth $H$, Magg V, Uch F, Mutz P, Klein P, Haneke K, et al. Flavivirus infection uncouples translation suppression from cellular stress responses. mBio. 2017; 8(1):e02150-16

84. Fritzlar S, Aktepe TE, Chao YW, Kenney ND, McAllaster MR, Wilen CB, et al. Mouse norovirus infection arrests host cell translation uncoupled from the stress granule-PKR-elF2a axis. mBio. 2019;10(3):e00960-19.

85. Brocard M, ladevaia V, Klein P, Hall B, Lewis G, Lu J, et al. Norovirus infection results in elF2a independent host translation shut-off and remodels the G3BP1 interactome evading stress granule formation. PLoS Pathog. 2020; 16(1):e1008250

86. Martínez-Salas E, Francisco-Velilla R, Fernandez-Chamorro J, Lozano G, DiazToledano R. Picornavirus IRES elements: RNA structure and host protein interactions. Virus Res. 2015;206:62-73.

87. Dave P, George B, Raheja H, Rani P, Behera P, Das S. The mammalian host protein DAP5 facilitates the initial round of translation of Coxsackievirus B3 RNA. J Biol Chem. 2019;294(42):15386-94.

88. Sanz MA, Almela EG, García-Moreno M, Marina Al, Carrasco L. A viral RNA motif involved in signaling the initiation of translation on non-AUG codons. RNA. 2019;25(4):431-52. 
89. Carrasco L, Sanz MA, González-Almela E. The regulation of translation in alphavirus-infected cells. Viruses. 2018;10(2):70.

90. Welnowska E, Sanz MA, Redondo N, Carrasco L. Translation of viral mRNA without active elF2: the case of picornaviruses. PLoS One. 2011;6(7):e22230.

91. Sanz MA, González Almela E, Carrasco L. Translation of sindbis subgenomic mRNA is independent of elF2, elF2A and elF2D. Sci Rep. 2017;7:43876.

92. Terenin IM, Dmitriev SE, Andreev DE, Shatsky IN. Eukaryotic translation initiation machinery can operate in a bacterial-like mode without elF2. Nat Struct Mol Biol. 2008;15(8):836-41.

93. Kim JH, Park SM, Park JH, Keum SJ, Jang SK. elF2A mediates translation of hepatitis C viral mRNA under stress conditions. EMBO J. 2011;30(12):245464.

94. Jaafar ZA, Oguro A, Nakamura Y, Kieft JS. Translation initiation by the hepatitis $C$ virus IRES requires elF1A and ribosomal complex remodeling. eLife. 2016:5:e21198.

95. González-Almela E, Williams H, Sanz MA, Carrasco L. The initiation factors elF2, elF2A, elF2D, elF4A, and elF4G are not involved in translation driven by hepatitis C virus IRES in human cells. Front Microbiol. 2018;9:207.

96. Kearse MG, Wilusz JE. Non-AUG translation: a new start for protein synthesis in eukaryotes. Genes Dev. 2017;31(17):1717-31.

97. Dai A, Cao S, Dhungel P, Luan Y, Liu Y, Xie Z, et al. Ribosome profiling reveals translational upregulation of cellular oxidative phosphorylation mRNAs during vaccinia virus-induced host shutoff. J Virol. 2017;91(5): e01858-16.

98. Mazzon M, Castro C, Thaa B, Liu L, Mutso M, Liu X, et al. Alphavirus-induced hyperactivation of PI3K/AKT directs pro-viral metabolic changes. PLoS Pathog. 2018;14(1):e1006835.

99. Harding HP, Novoa I, Zhang Y, Zeng H, Wek R, Schapira M, et al. Regulated translation initiation controls stress-induced gene expression in mammalian cells. Mol Cell. 2000;6(5):1099-108.

100. Anderson P, Kedersha N. Stress granules. Curr Biol. 2009;19(10):R397-8

101. Yang P, Mathieu C, Kolaitis RM, Zhang P, Messing J, Yurtsever U, et al. G3BP1 is a tunable switch that triggers phase separation to assemble stress granules. Cell. 2020;181(2):325-45.e28.

102. Protter DSW, Parker R. Principles and properties of stress granules. Trends Cell Biol. 2016;26(9):668-79.

103. Ivanov $P$, Kedersha N, Anderson P. Stress granules and processing bodies in translational control. Cold Spring Harb Perspect Biol. 2019;11(5):a032813.

104. Kedersha NL, Gupta M, Li W, Miller I, Anderson P. RNA-binding proteins TIA1 and TIAR link the phosphorylation of elF-2 alpha to the assembly of mammalian stress granules. J Cell Biol. 1999;147(7):1431-42.

105. Kedersha N, Anderson P. Stress granules: sites of mRNA triage that regulate mRNA stability and translatability. Biochem Soc Trans. 2002;30(Pt 6):963-9.

106. Onomoto K, Jogi M, Yoo JS, Narita R, Morimoto S, Takemura A, et al. Critical role of an antiviral stress granule containing RIG-I and PKR in viral detection and innate immunity. PLOS One. 2012;7(8):e43031.

107. Kang JS, Hwang YS, Kim LK, Lee S, Lee WB, Kim-Ha J, et al. OASL1 traps viral RNAs in stress granules to promote antiviral responses. Mol Cells. 2018;41(3) 214-23.

108. Zhai $X$, Wu S, Lin L, Wang T, Zhong $X$, Chen Y, et al. Stress granule formation is one of the early antiviral mechanisms for host cells against coxsackievirus B infection. Virol Sin. 2018;33(4):314-22.

109. Bonenfant G, Williams N, Netzband R, Schwarz MC, Evans MJ, Pager CT. Zika virus subverts stress granules to promote and restrict viral gene expression. J Virol. 2019;93(12):e00520-19.

110. Yang X, Hu Z, Fan S, Zhang Q, Zhong Y, Guo D, et al. Picornavirus $2 A$ protease regulates stress granule formation to facilitate viral translation. PLoS Pathog. 2018;14(2):e1006901.

111. Zhang Y, Yao L, Xu X, Han H, Li P, Zou D, et al. Enterovirus 71 inhibits cytoplasmic stress granule formation during the late stage of infection. Virus Res. 2018;255:55-67.

112. White JP, Cardenas AM, Marissen WE, Lloyd RE. Inhibition of cytoplasmic mRNA stress granule formation by a viral proteinase. Cell Host Microbe. 2007;2(5):295-305.

113. Visser L, Medina GN, Rabouw HH, de Groot RJ, Langereis MA, de Los Santos T, et al. Foot-and-mouth disease virus leader protease cleaves G3BP1 and G3BP2 and inhibits stress granule formation. J Virol. 2019;93(2):e0092218.

114. Yang X, Hu Z, Zhang Q, Fan S, Zhong Y, Guo D, et al. SG formation relies on elF4Gl-G3BP interaction which is targeted by picornavirus stress antagonists. Cell Discov. 2019;5:1
115. Hu Z, Wang Y, Tang Q, Yang X, Qin Y, Chen M. Inclusion bodies of human parainfluenza virus type 3 inhibit antiviral stress granule formation by shielding viral RNAs. PLoS Pathog. 2018;14(3):e1006948.

116. Rao S, Cinti A, Temzi A, Amorim R, You JC, Mouland AJ. HIV-1 NC-induced stress granule assembly and translation arrest are inhibited by the dsRNA binding protein Staufen1. RNA. 2018;24(2):219-36.

117. Rao S, Hassine S, Monette A, Amorim R, DesGroseillers L, Mouland AJ. HIV-1 requires Staufen 1 to dissociate stress granules and to produce infectious viral particles. RNA. 2019;25(6):727-36.

118. Zhu $Y$, Wang B, Huang $H$, Zhao Z. Enterovirus 71 induces anti-viral stress granule-like structures in RD cells. Biochem Biophys Res Commun. 2016; 476(4):212-7.

119. Visser LJ, Langereis MA, Rabouw HH, Wahedi M, Muntjewerff EM, de Groot $\mathrm{RJ}$, et al. Essential role of enterovirus 2A protease in counteracting stress granule formation and the induction of type I interferon. J Virol. 2019;93(10): e00222-19.

120. Borghese F, Michiels T. The leader protein of cardioviruses inhibits stress granule assembly. J Virol. 2011;85(18):9614-22.

121. Song $L$, Han $X$, Jia $C$, Zhang $X$, Jiao $Y$, Du T, et al. Porcine reproductive and respiratory syndrome virus inhibits MARC-145 proliferation via inducing apoptosis and G2/M arrest by activation of Chk/Cdc25C and p53/p21 pathway. Virol J. 2018;15(1):169.

122. Bressy C, Droby GN, Maldonado BD, Steuerwald N, Grdzelishvili VZ. Cell cycle arrest in $\mathrm{G}(2) / \mathrm{M}$ phase enhances replication of interferon-sensitive cytoplasmic RNA viruses via inhibition of antiviral gene expression. J Virol. 2019;93(4):e01885-18.

123. Liu Y, László C, Liu Y, Liu W, Chen X, Evans SC, et al. Regulation of G(1) arrest and apoptosis in hypoxia by PERK and GCN2-mediated elF2alpha phosphorylation. Neoplasia. 2010;12(1):61-8.

124. Wang Y, Wang R, Li Y, Sun Y, Song C, Zhan Y, et al. Newcastle disease virus induces $\mathrm{G}(0) / \mathrm{G}(1)$ cell cycle arrest in asynchronously growing cells. Virology. 2018;520:67-74

125. Wang Q, Yuan X, Chen Y, Zheng Q, Xu L, Wu Y. Endoplasmic reticulum stress mediated MDRV p10.8 protein-induced cell cycle arrest and apoptosis through the PERKVelF2a pathway. Front Microbiol. 2018;9:1327.

126. He Y, Xu K, Keiner B, Zhou J, Czudai V, Li T, et al. Influenza A virus replication induces cell cycle arrest in G0/G1 phase. J Virol. 2010;84(24): 12832-40.

127. Wang Z, Wang Y, Wang S, Meng X, Song F, Huo W, et al. Coxsackievirus A6 induces cell cycle arrest in G0/G1 phase for viral production. Front Cell Infect Microbiol. 2018;8:279.

128. Tallóczy Z, Jiang W, Virgin HW, Leib DA, Scheuner D, Kaufman RJ, et al. Regulation of starvation- and virus-induced autophagy by the elF2alpha kinase signaling pathway. Proc Natl Acad Sci U S A. 2002;99(1):190-5.

129. Vattem KM, Wek RC. Reinitiation involving upstream ORFs regulates ATF4 mRNA translation in mammalian cells. Proc Natl Acad Sci U S A. 2004; 101(31):11269-74

130. Matsumoto H, Miyazaki S, Matsuyama S, Takeda M, Kawano M, Nakagawa H, et al. Selection of autophagy or apoptosis in cells exposed to ER-stress depends on ATF4 expression pattern with or without CHOP expression. Biol Open. 2013;2(10):1084-90.

131. Frank CL, Ge X, Xie Z, Zhou Y, Tsai LH. Control of activating transcription factor 4 (ATF4) persistence by multisite phosphorylation impacts cell cycle progression and neurogenesis. J Biol Chem. 2010;285(43):33324-37.

132. Harding HP, Zhang $Y$, Zeng $H$, Novoa I, Lu PD, Calfon M, et al. An integrated stress response regulates amino acid metabolism and resistance to oxidative stress. Mol Cell. 2003;11(3):619-33.

133. Kim W, Bennett EJ, Huttlin EL, Guo A, Li J, Possemato A, et al. Systematic and quantitative assessment of the ubiquitin-modified proteome. Mol Cell. 2011;44(2):325-40

134. Bagheri-Yarmand R, Sinha KM, Gururaj AE, Ahmed Z, Rizvi YQ, Huang SC, et al. A novel dual kinase function of the RET proto-oncogene negatively regulates activating transcription factor 4-mediated apoptosis. J Biol Chem. 2015;290(18):11749-61.

135. Gachon F, Devaux C, Mesnard JM. Activation of HTLV-I transcription in the presence of tax is independent of the acetylation of CREB-2 (ATF-4). Virology. 2002;299(2):271-8.

136. Yuniati $L$, van der Meer $L T$, Tijchon $E$, van Ingen Schenau $D$, van Emst L, Levers M, et al. Tumor suppressor BTG1 promotes PRMT1-mediated ATF4 function in response to cellular stress. Oncotarget. 2016;7(3): $3128-43$. 
137. Huggins CJ, Mayekar MK, Martin N, Saylor KL, Gonit M, Jailwala P, et al. C/ EBPY is a critical regulator of cellular stress response networks through heterodimerization with ATF4. Mol Cell Biol. 2015;36(5):693-713.

138. Wortel IMN, van der Meer LT, Kilberg MS, van Leeuwen FN. Surviving stress: modulation of ATF4-mediated stress responses in normal and malignant cells. Trends Endocrinol Metab. 2017;28(11):794-806.

139. B'Chir W, Maurin AC, Carraro V, Averous J, Jousse C, Muranishi Y, et al. The elF2a/ATF4 pathway is essential for stress-induced autophagy gene expression. Nucleic Acids Res. 2013;41(16):7683-99.

140. Mizushima N, Komatsu M. Autophagy: renovation of cells and tissues. Cell. 2011;147(4):728-41.

141. Romao S, Gasser N, Becker AC, Guhl B, Bajagic M, Vanoaica D, et al. Autophagy proteins stabilize pathogen-containing phagosomes for prolonged MHC II antigen processing. J Cell Biol. 2013;203(5):757-66.

142. English L, Chemali M, Duron J, Rondeau C, Laplante A, Gingras D, et al. Autophagy enhances the presentation of endogenous viral antigens on MHC class I molecules during HSV-1 infection. Nat Immunol. 2009;10(5):4807.

143. Dengjel J, Schoor O, Fischer R, Reich M, Kraus M, Müller M, et al. Autophagy promotes MHC class II presentation of peptides from intracellular source proteins. Proc Natl Acad Sci U S A. 2005;102(22):7922-7.

144. Dreux M, Gastaminza P, Wieland SF, Chisari FV. The autophagy machinery is required to initiate hepatitis $C$ virus replication. Proc Natl Acad Sci U S A. 2009;106(33):14046-51

145. Sun P, Zhang S, Qin X, Chang X, Cui X, Li H, et al. Foot-and-mouth disease virus capsid protein VP2 activates the cellular EIF2S1-ATF4 pathway and induces autophagy via HSPB1. Autophagy. 2018;14(2):336-46.

146. Fu L, Fu X, Mo J, Li X, Li R, Peng S. miR-146a-5p enhances hepatitis B virus replication through autophagy to promote aggravation of chronic hepatitis B. IUBMB Life. 2019;71(9):1336-46.

147. Yin $H$, Zhao L, Jiang $X$, Li S, Huo $H$, Chen $H$. DEV induce autophagy via the endoplasmic reticulum stress related unfolded protein response. PLoS One. 2017;12(12):e0189704.

148. Luo XN, Yao HL, Song J, Song QQ, Shi BT, Xia D, et al. Coxsackievirus B3 infection triggers autophagy through 3 pathways of endoplasmic reticulum stress. Biomed Environ Sci. 2018:31(12):867-75.

149. Yuan P, Dong L, Cheng Q, Wang S, Li Z, Sun Y, et al. Prototype foamy virus elicits complete autophagy involving the ER stress-related UPR pathway. Retrovirology. 2017;14(1):16.

150. Zhou YS, Gu YX, Qi BZ, Zhang YK, Li XL, Fang WH. Porcine circovirus type 2 capsid protein induces unfolded protein response with subsequent activation of apoptosis. J Zhejiang Univ Sci B. 2017;18(4):316-23.

151. Wang Q, Xin X, Wang T, Wan J, Ou Y, Yang Z, et al. Japanese encephalitis virus induces apoptosis and encephalitis by activating the PERK pathway. J Virol. 2019;93(17):e00887-19.

152. Isobe T, Tange S, Tasaki H, Kanamori K, Kato A, Nakanishi A. Upregulation of CHOP participates in caspase activation and virus release in human astrovirus-infected cells. J Gen Virol. 2019;100(5):778-92.

153. Medigeshi GR, Lancaster AM, Hirsch AJ, Briese T, Lipkin WI, Defilippis V, et al. West Nile virus infection activates the unfolded protein response, leading to CHOP induction and apoptosis. J Virol. 2007;81(20):10849-60.

154. Zhang F, Moon A, Childs K, Goodbourn S, Dixon LK. The African swine fever virus DP71L protein recruits the protein phosphatase 1 catalytic subunit to dephosphorylate elF2alpha and inhibits CHOP induction but is dispensable for these activities during virus infection. J Virol. 2010;84(20):10681-9.

155. Li J, He J, Fu Y, Hu X, Sun LQ, Huang Y, et al. Hepatitis B virus X protein inhibits apoptosis by modulating endoplasmic reticulum stress response. Oncotarget. 2017:8(56):96027-34.

156. Novoa I, Zeng H, Harding HP, Ron D. Feedback inhibition of the unfolded protein response by GADD34-mediated dephosphorylation of elF2alpha. J Cell Biol. 2001;153(5):1011-22.

157. Ma Y, Hendershot LM. Delineation of a negative feedback regulatory loop that controls protein translation during endoplasmic reticulum stress. J Biol Chem. 2003;278(37):34864-73.

158. Brush MH, Weiser DC, Shenolikar S. Growth arrest and DNA damageinducible protein GADD34 targets protein phosphatase 1 alpha to the endoplasmic reticulum and promotes dephosphorylation of the alpha subunit of eukaryotic translation initiation factor 2. Mol Cell Biol. 2003;23(4): 1292-303.

159. Liao Y, Gu F, Mao X, Niu Q, Wang H, Sun Y, et al. Regulation of de novo translation of host cells by manipulation of PERK/PKR and GADD34-PP1 activity during Newcastle disease virus infection. J Gen Virol. 2016;97(4):86779.

160. Rojas M, Vasconcelos G, Dever TE. An elF2a-binding motif in protein phosphatase 1 subunit GADD34 and its viral orthologs is required to promote dephosphorylation of elF2a. Proc Natl Acad Sci U S A. 2015; 112(27):E3466-75.

161. Carrara M, Sigurdardottir A, Bertolotti A. Decoding the selectivity of elF2a holophosphatases and PPP1R15A inhibitors. Nat Struct Mol Biol. 2017;24(9): 708-16

162. Fusade-Boyer M, Dupré G, Bessière P, Khiar S, Quentin-Froignant C, Beck C, et al. Evaluation of the antiviral activity of sephin1 treatment and its consequences on elF2a phosphorylation in response to viral infections. Front Immunol. 2019;10:134.

163. El-Serag HB, Kanwal F, Davila JA, Kramer J, Richardson P. A new laboratorybased algorithm to predict development of hepatocellular carcinoma in patients with hepatitis C and cirrhosis. Gastroenterology. 2014;146(5):124955.e1.

164. Affo S, Yu LX, Schwabe RF. The role of cancer-associated fibroblasts and fibrosis in liver cancer. Annu Rev Pathol. 2017;12:153-86.

165. Zheng Y, Liu P, Wang N, Wang S, Yang B, Li M, et al. Betulinic acid suppresses breast cancer metastasis by targeting GRP78-mediated glycolysis and ER stress apoptotic pathway. Oxidative Med Cell Longev. 2019;2019: 8781690.

166. Albert AE, Adua SJ, Cai WL, Arnal-Estapé A, Cline GW, Liu Z, et al. Adaptive protein translation by the integrated stress response maintains the proliferative and migratory capacity of lung adenocarcinoma cells. Mol Cancer Res. 2019;17(12):2343-55.

\section{Publisher's Note}

Springer Nature remains neutral with regard to jurisdictional claims in published maps and institutional affiliations.
Ready to submit your research? Choose BMC and benefit from:

- fast, convenient online submission

- thorough peer review by experienced researchers in your field

- rapid publication on acceptance

- support for research data, including large and complex data types

- gold Open Access which fosters wider collaboration and increased citations

- maximum visibility for your research: over $100 \mathrm{M}$ website views per year

At BMC, research is always in progress.

Learn more biomedcentral.com/submissions 